Research papers

\title{
Methane in the South China Sea and the Western Philippine Sea
}

\author{
Hsiao-Chun Tseng ${ }^{\mathrm{a}, \mathrm{b}}$, Chen-Tung Arthur Chen ${ }^{\mathrm{b}, *}$, Alberto V. Borges ${ }^{\mathrm{c}}, \mathrm{T}$. Angel DelValls ${ }^{\mathrm{a}}$, \\ Yu-Chang Chang ${ }^{\mathrm{b}}$ \\ ${ }^{a}$ UNESCO UNITWIN/WiCop. Physical Chemistry Department. Faculty of Marine and Environmental Sciences, Poligono río San Pedro s/n, University of \\ Cadiz, 11519, Puerto Real, Cadiz, Spain \\ b Department of Oceanography, National Sun Yat-sen University, Kaohsiung 804, Taiwan \\ c Université de Liège, Unité d'Océanographie Chimique, Institut de Physique (B5), B-4000, Belgium
}

\section{A R T I C L E I N F O}

\section{Keywords:}

South China Sea

Western Philippine Sea

$\mathrm{CH}_{4}$

Sea-to-air flux

Chlorophyll $a$

Gas hydrates

\begin{abstract}
A B S T R A C T
Approximately 700 water samples from the South China Sea (SCS) and 300 water samples from the western Philippine Sea (wPS) were collected during eight cruises from August 2003 to July 2007 to determine methane $\left(\mathrm{CH}_{4}\right)$ distributions from the surface to a depth of $4250 \mathrm{~m}$. The surface $\mathrm{CH}_{4}$ concentrations exceeded atmospheric equilibrium, both in the SCS and the wPS, and the concentrations were $4.5 \pm 3.6$ and $3.0 \pm$ $1.2 \mathrm{nmol} \mathrm{L}^{-1}$, respectively. The sea-to-air fluxes were calculated, and the SCS and the wPS were found to emit $\mathrm{CH}_{4}$ to the atmosphere at $8.6 \pm 6.4 \mu \mathrm{mol} \mathrm{m}{ }^{-2} \mathrm{~d}^{-1}$ and $4.9 \pm 4.9 \mu \mathrm{mol} \mathrm{m}^{-2} \mathrm{~d}^{-1}$, respectively. In the $\mathrm{SCS}, \mathrm{CH}_{4}$ emissions were higher over the continental shelf $\left(11.0 \pm 7.4 \mu \mathrm{mol} \mathrm{m}^{-2} \mathrm{~d}^{-1}\right)$ than over the deep ocean $(6.1 \pm$ $6.0 \mu \mathrm{mol} \mathrm{m} \mathrm{m}^{-2} \mathrm{~d}^{-1}$ ), owing to greater biological productivity and closer coupling with the sediments on the continental shelf. The SCS emitted $30.1 \times 10^{6} \mathrm{~mol} \mathrm{~d}^{-1} \mathrm{CH}_{4}$ to the atmosphere and exported $1.82 \times 10^{6} \mathrm{~mol} \mathrm{~d}^{-1}$ $\mathrm{CH}_{4}$ to the wPS.

The concentrations of both $\mathrm{CH}_{4}$ and chlorophyll $a$ were high in the $150 \mathrm{~m}$ surface layer of the wPS, but were not significantly correlated with each other. $\mathrm{CH}_{4}$ concentrations generally declined with increasing depth below the euphotic zone but remained constant below $1,000 \mathrm{~m}$, both in the SCS and the wPS. Some high $\mathrm{CH}_{4}$ concentrations were observed at mid-depths and bottom waters in the SCS, and were most likely caused by the release of $\mathrm{CH}_{4}$ from gas hydrates or gas seepage.
\end{abstract}

\section{Introduction}

Methane $\left(\mathrm{CH}_{4}\right)$, the most abundant hydrocarbon in the atmosphere, has a global warming potential in a 100-year time frame $\left(\mathrm{GWP}_{100}\right)$ that is 34 times that of carbon dioxide $\left(\mathrm{CO}_{2}\right)$, and plays an important role in the atmospheric chemistry (Naqvi et al., 2010; IPCC, 2013).

The global atmospheric concentration of $\mathrm{CH}_{4}$ has increased exponentially from a pre-industrial value of about $722 \pm 25 \mathrm{ppb}$ in 1750 to $1803 \pm 2 \mathrm{ppb}$ in 2011 (IPCC, 2013). This increase in $\mathrm{CH}_{4}$ concentration is very likely caused by anthropogenic activities, predominantly agriculture and combustion of fossil fuels, but the relative contributions of different sources have not been well determined (IPCC, 2013). Kirschke et al. (2013) stated that the surface-to-air global $\mathrm{CH}_{4}$ emission from 2000 to 2009 was $678 \mathrm{Tg} \mathrm{CH}_{4} \mathrm{yr}^{-1}$, with a large range (542-852 $\mathrm{Tg} \mathrm{CH}_{4} \mathrm{yr}^{-1}$ ). The ocean emits $\mathrm{CH}_{4}$ to the atmosphere at a rate of less than $2 \mathrm{Tg} \mathrm{CH}_{4} \mathrm{yr}^{-1}$ (Rhee et al., 2009) and its contribution to the atmospheric $\mathrm{CH}_{4}$ budget is minor (around 2\%). However, the impingement of human activities on oceanic $\mathrm{CH}_{4}$ emissions, such as waste water discharge into the coastal areas, unlike on terrestrial emissions, is not well understood and has been poorly quantified (Naqvi et al., 2010). Especially, continental shelves and estuaries contribute approximately $75 \%$ of global oceanic $\mathrm{CH}_{4}$ emissions (Bange et al., 1994), and $\mathrm{CH}_{4}$ emissions from these environments are probably higher due to the contribution from sedimentary sources in well-mixed coastal zones (Borges et al., 2016).

The oversaturation of $\mathrm{CH}_{4}$ in the oxygenated ocean surface mixed layer has been widely known for more than four decades (Lamontagne et al., 1973; Scranton and Brewer, 1977; Forster et al., 2008). The $\mathrm{CH}_{4}$ concentrations in near-surface waters throughout much of the world's oceans are $5-75 \%$ oversaturated with respect to the atmospheric equilibrium (Karl et al., 2008). Previous research has revealed that $\mathrm{CH}_{4}$ is released during zooplankton grazing (de Angelis and Lee, 1994) or is formed in anoxic microenvironments within zooplankton fecal pellets (Traganza et al., 1979; de Angelis and Lee, 1994; Karl and Tilbrook, 1994), which are mostly found in the euphotic zone. Recent

\footnotetext{
* Corresponding author.

E-mail address: ctchen@mail.nsysu.edu.tw (C.-T.A. Chen).
} 
research has also determined that the formation of $\mathrm{CH}_{4}$ in oxic environments can occur via methylphosphonate cycling in subtropical gyres, which are phosphate-depleted (Karl et al., 2008), and by dimethylsulfide (DMS) cycling in both polar and tropical oligotrophic waters (Damm et al., 2010; Zindler et al., 2013). Florez-Leiva et al. (2013) suggested that the $\mathrm{CH}_{4}$ production may be induced by DMS cycling in the surface water of an upwelling ecosystem off central Chile in which nutrient depletion has never been observed even in winter (Morales and Anabalón, 2012). Overall, the enhancement of primary production may lead to increased $\mathrm{CH}_{4}$ concentrations, which has led Bogart et al. (2014) to suggest the possibility of a relationship between $\mathrm{CH}_{4}$ concentration and phytoplankton standing stocks (i. e. chlorophyll a).

Only recently has $\mathrm{CH}_{4}$ in the South China Sea (SCS) and the western Philippine Sea (wPS) been studied and the focus has usually been on the surface water (Chen et al., 1994; Rehder and Suess, 2001), the bottom water and sediments (Chuang et al., 2006; Yang et al., 2006). Chen and Tseng (2006), Chen et al. (2008a, 2008b) and Zhou et al. (2009) reported the $\mathrm{CH}_{4}$ distribution in the water column of the SCS but the study was only local. Here, for the first time we investigated the $\mathrm{CH}_{4}$ distribution throughout the SCS and the wPS. Our results elucidate the spatial and vertical distributions of $\mathrm{CH}_{4}$ in the water column of the SCS and wPS, as well as its sea-to-air fluxes. Further, we discuss differences between these seas and factors that influence the distribution and fluxes of $\mathrm{CH}_{4}$.

\section{Materials and methods}

\subsection{Study area}

The SCS is a semi-enclosed marginal sea off the Asian continent in the West Pacific. It is the largest marginal sea in the world with an area of $3.5 \times 10^{6} \mathrm{~km}^{2}$ and an average depth of $1350 \mathrm{~m}$. The SCS properly characterized by either a tropical or subtropical climate has both deep basin and extensive shelf systems at its northern and southern boundaries, which are associated with large riverine inputs. At the southern edge of the SCS lies the Sunda Shelf, which connects the sea to the Straits of Malacca and has an average depth of approximately $50 \mathrm{~m}$. The eastern part of the SCS is connected with the Sulu Sea through the Mindoro Strait, and the northern part of the SCS is connected with the East China Sea through the Taiwan Strait. The northeastern SCS is connected with the wPS via the Luzon Strait, which is around $2200 \mathrm{~m}$ in depth and has the deepest sill that connects the SCS with any adjacent body of water. The SCS also features dynamic exchange with the wPS via an upper water exchanges with the Kuroshio and inflow at depth (Chen et al., 2001; Dai et al., 2013; Du et al., 2013).

The Asian monsoon dominates climatic variations at the sea-air interface of the SCS. The southwest monsoon season runs from May to October and brings a large amount of rainfall. The northeast monsoon season runs from November to April and is characterized by the high wind speeds (Han, 1998).

The wPS is located in the western part of the North Pacific from $123^{\circ} \mathrm{E}$ to $135^{\circ} \mathrm{E}$ and from $10^{\circ} \mathrm{N}$ to $35^{\circ} \mathrm{N}$. The mean depth of the wPS is about $5500 \mathrm{~m}$. This study focuses on the area between $120.5^{\circ} \mathrm{E}$ and $130^{\circ} \mathrm{E}$ and between $21^{\circ} \mathrm{N}$ and $28^{\circ} \mathrm{N}$, where the wPS connects with the SCS and water masses exchange frequently.

\subsection{Water samples collections}

Samples were taken during six cruises on board R/V Ocean Researchers I and III in the SCS (Fig. 1a; Table 1): ORIII-896 (August, 2003), ORI-695 (September, 2003), ORIII-983 (July, 2004), ORIII-1081 (July, 2005), ORI-802 (July, 2006) and ORI-837 (July, 2007).

In this study, four contrasting physical-biogeochemical domains (Table 1) are examined to provide a better understanding of the spatial variability of $\mathrm{CH}_{4}$ distributions and fluxes in the SCS. Domain A is in the northeastern part of the SCS, close to the south of the Taiwan Strait. Samples were collected in domain A during the ORIII-896 and ORIII-983 cruises in August 2003 and July 2004, respectively. This area is affected by Kuroshio intrusions, which generate various mesoscale eddies, upwelling and internal waves (Yuan et al., 2008; Sheu et al., 2010; Chen et al., 2015; Huang et al., 2015). Cruises ORI695 and ORIII-1081 were conducted in September 2003 and July 2005, respectively in domain B in the wet season when the Pearl River exhibited a large discharge (Chen et al., 2008a; Gan et al., 2009; Cao et al., 2011; Han et al., 2012). The Pearl River (Zhujiang) is the second largest river (after the Mekong River) that enters the SCS (Chen et al., 2008a). Domain C is located in the southwestern part of the SCS. In July 2006, samples were taken during the ORI-802 cruise from domain $\mathrm{C}$ and time-series station SCS1, which was located in domain B. Some sampling stations were on the Sunda Shelf and others were off the Sunda Shelf and on the continental slope, where the depth increases sharply. Domain D is located from the eastern part to the southern part of the SCS. The samples in domain D were taken during July 16-31 of 2007 during the ORI-837 cruise. Surface water samples were taken from the Luzon Strait and along the western coast of Luzon Island, Palawan Island and northwestern coast of Borneo Island. Discrete water samples were taken at various depths from the eastern part of the SCS to the southern part of the SCS.

Samples from the wPS were collected during three cruises (Fig. 1b). Discrete water samples were taken at various depths on ORI-725 (July, 2004) and ORIII-1149 (May, 2006). These two cruises were carried out along $22^{\circ} \mathrm{N}$ from $121^{\circ} \mathrm{E}$ to $126^{\circ} \mathrm{E}$ in July 2004 and from $121^{\circ} \mathrm{E}$ to $124^{\circ} \mathrm{E}$ in May 2006. Surface water samples were taken from the northeastern coast of Taiwan to the Luzon Strait on ORI-837 (July, 2007). The analysis herein also included a very limited $\mathrm{CH}_{4}$ data-set which was obtained from 25 samples from surface waters collected exclusively in the wPS in various cruises in the years 1992-1996.

Water samples from various areas and depths were collected using a Rosette sampler that was fitted with $5 \mathrm{~L}$ or $10 \mathrm{~L}$ Niskin bottles, along with a conductivity-temperature-depth (CTD) probe (Sea-Bird 911, USA). Saturated $\mathrm{HgCl}_{2}$ was added to all samples to inhibit microbial activity, except for those samples that were used to measure salinity. Temperature data were obtained from the CTD profiles, whereas the salinity values that were used in the analysis were determined from discrete AUTOSAL measurements.

Water samples for measuring $\mathrm{CH}_{4}$ concentration were collected in $120 \mathrm{~mL}$ dark glass bottles. The bottles were rinsed three times with the sampled water. After 1-2 fold of bottle volume was allowed to overflow the bottle, $10 \mathrm{~mL}$ of the water sample was withdrawn from the bottle to create an air space, and $0.5 \mathrm{~mL}$ saturated $\mathrm{HgCl}_{2}$ was then added. The sample bottles were then immediately sealed with a butyl rubber stopper and an aluminum cap. The samples were stored at $4{ }^{\circ} \mathrm{C}$ in the dark. All the water samples were transferred to a laboratory and analyzed within three months of collection.

\subsection{Atmospheric air samples collections}

Atmospheric $\mathrm{CH}_{4}$ samples were collected using modified version of the sampling method of Chang and Yang (1997). A $12 \mathrm{~mL}$ disposable plastic syringe with an $8 \mathrm{~cm}$-long plastic tube was used to withdraw $12 \mathrm{~mL}$ of air four times from a $12 \mathrm{~mL}$ serum bottle to increase the exchange of the atmospheric gas into the $12 \mathrm{~mL}$ serum bottle. The serum bottle was then sealed with a butyl rubber stopper and an aluminum cap. While making CTD casting, gas samples were taken on the top deck to collect clean air, facing into the wind to prevent contamination by the emissions of the ship.

\subsection{Chemical analysis}

The salinity of the discrete samples was determined by measuring 
(a)
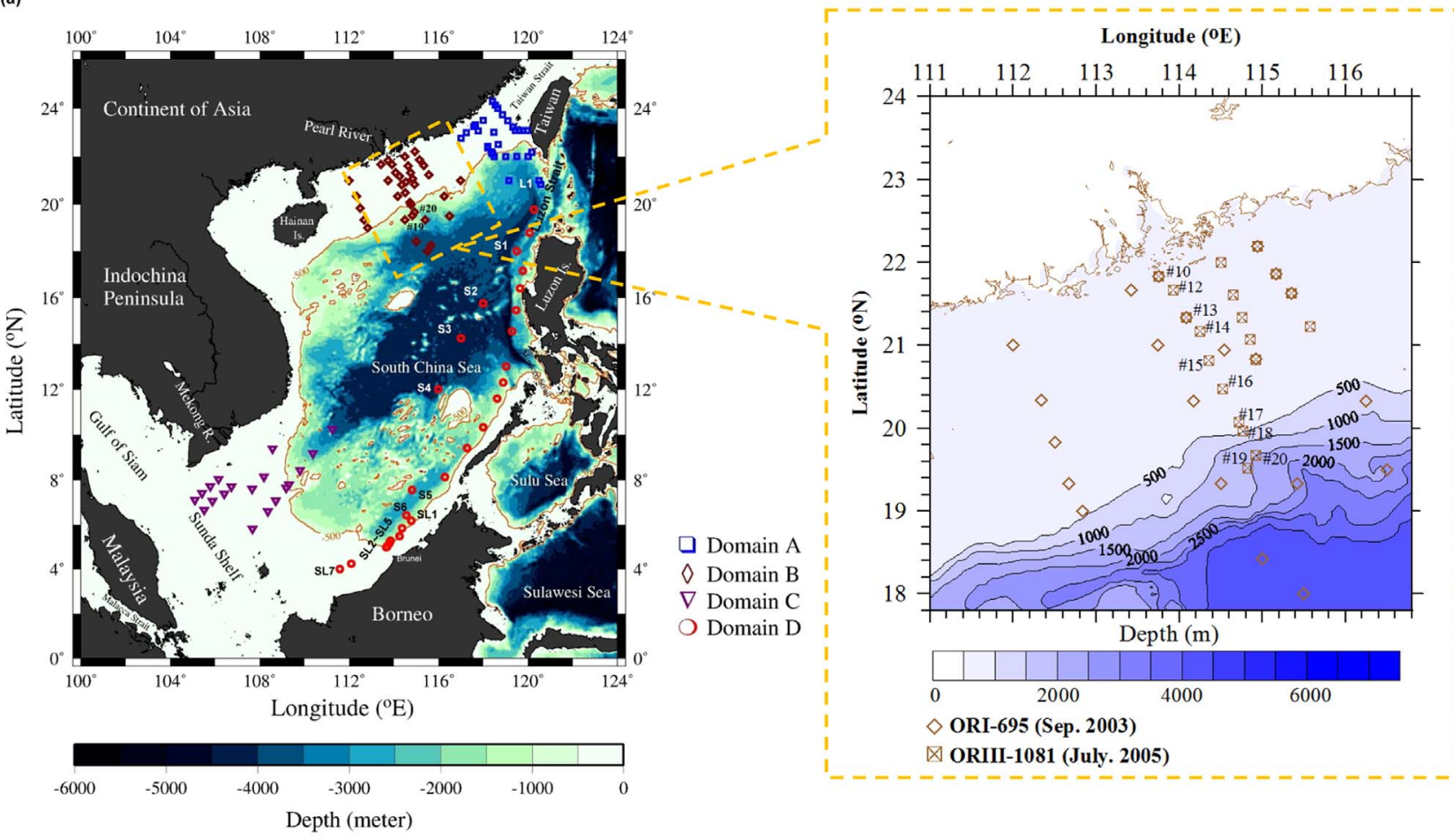

(b)

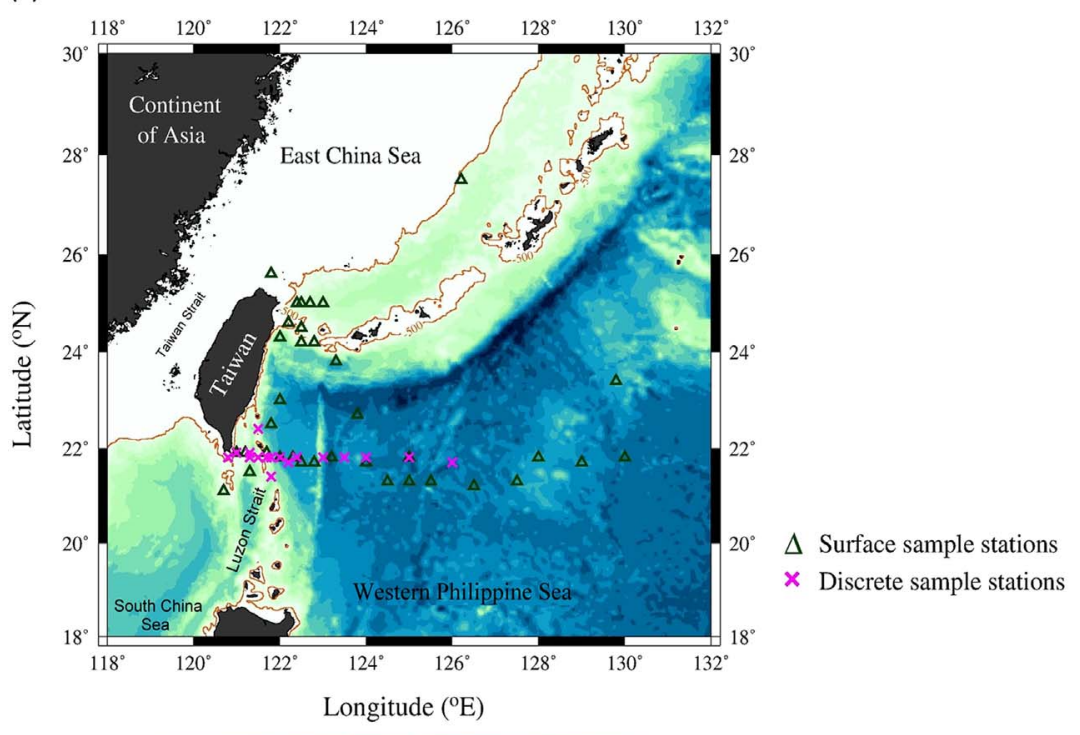

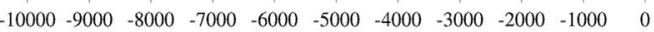

Depth (meter)

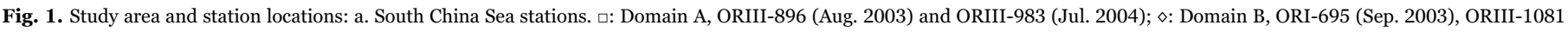

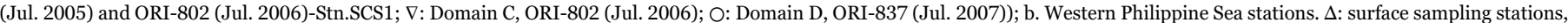

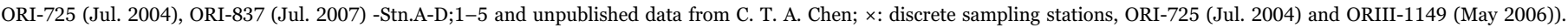

conductivity using an AUTOSAL salinometer, which was calibrated with standard seawater (batch no. P141) from the International Association for the Physical Sciences of the Oceans (IAPSO). The precision of the measurements was \pm 0.003 salinity unit. Chlorophyll $a$ samples were collected by filtration through a $0.45 \mu \mathrm{m}$ diameter Millipore polycarbonate filter. A Turner Designs model 10-AU fluorometer (Varian Eclipse) was utilized to measure chlorophyll $a$ concentration following extraction by $90 \%$ acetone (Strickland and Parsons, 1972) with a precision of $\pm 5 \%$.

The concentration of dissolved $\mathrm{CH}_{4}$ was estimated by the modified head-space equilibrium method (Johnson et al., 1990) using a gas chromatograph (GC; HP 5890 Series II) that was equipped with a flame ionization detector (FID). The samples were placed in a water bath at a constant temperature of $25^{\circ} \mathrm{C}$, and allowed to equilibrate for at least three hours. Finally, $2 \mathrm{~mL}$ of the gas from the headspace was injected into the GC. The GC-FID had a 6 foot-long stainless steel column with a diameter of one-eighth of an inch, which was filled with a 60/80 mesh molecular sieve $5 \mathrm{~A}$. The primary standard was NIST (National

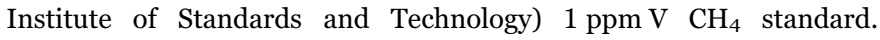
Mixtures of $\mathrm{CH}_{4}$ in $\mathrm{N}_{2}$ at concentrations of 0 (Jing-Shang, Taiwan), 1 
Table 1

Surface $\mathrm{CH}_{4}$ concentrations and sea-to-air fluxes in the SCS and the wPS in the wet season.

\begin{tabular}{|c|c|c|c|c|c|c|c|c|c|}
\hline & & & $\begin{array}{l}\text { Latitude } \\
\left({ }^{\circ} \mathrm{N}\right)\end{array}$ & $\begin{array}{l}\text { Longitude } \\
\left({ }^{\circ} \mathrm{E}\right)\end{array}$ & Sal. & $\begin{array}{l}\text { Average Surface } \\
\mathrm{CH}_{4} \text { Concentration } \\
\left(\mathrm{nmol} \mathrm{L}^{-1}\right)\end{array}$ & $\begin{array}{l}\text { Wind Speed } \\
(\mathrm{m} / \mathrm{s})\end{array}$ & $\begin{array}{l}\text { Sea-to-Air Flux } \\
\left(\mu \mathrm{mol} \mathrm{m}{ }^{-2} \mathrm{~d}^{-1}\right)\end{array}$ & Surveying Cruises/Months \\
\hline \multirow[t]{7}{*}{ SCS } & \multirow[t]{4}{*}{ Domain } & A & $20-25$ & $117-120$ & $33.86 \pm 0.34$ & $4.5 \pm 2.3(\mathrm{n}=31)$ & $7.2 \pm 1.8$ & $9.9 \pm 8.7$ & $\begin{array}{l}\text { ORIII-896 (Aug. 2003) } \\
\text { ORIII-983 (Jul. 2004) }\end{array}$ \\
\hline & & B & $17-23$ & $112-117$ & $33.17 \pm 1.08$ & $5.2 \pm 2.1(n=42)$ & $7.0 \pm 1.3$ & $12.0 \pm 7.4$ & $\begin{array}{l}\text { ORI-695 (Sep. 2003) } \\
\text { ORIII-1081 (Jul. 2005) } \\
\text { ORI-802 (Jul. 2006)-Stn. SCS1 }\end{array}$ \\
\hline & & $\mathrm{C}$ & $3-12$ & $104-113$ & $33.23 \pm 0.19$ & $4.9 \pm 1.5(n=19)$ & $6.2 \pm 1.0$ & $8.3 \pm 4.1$ & ORI-802 (Jul. 2006) \\
\hline & & $\mathrm{D}$ & $4-20$ & $110-120$ & $32.87 \pm 1.00$ & $3.4 \pm 1.0(n=30)$ & $6.3 \pm 0.9$ & $4.3 \pm 3.9$ & ORI-837 (Jul. 2007) \\
\hline & Avg. & & $3-25$ & $104-120$ & $33.28 \pm 1.5$ & $4.5 \pm 3.6(n=122)$ & $6.3 \pm 0.8$ & $8.6 \pm 6.4$ & \\
\hline & \multirow{2}{*}{\multicolumn{4}{|c|}{$\begin{array}{l}\text { Avg. Continental Shelf and upper slope region (depth < } \\
500 \mathrm{~m} \text { ) } \\
\text { Avg. Deep Sea (depth }>500 \mathrm{~m})\end{array}$}} & $33.29 \pm 0.9$ & $5.1 \pm 2.1(n=72)$ & & $11.0 \pm 7.4$ & \\
\hline & & & & & $33.54 \pm 0.7$ & $3.8 \pm 1.6(n=50)$ & & $6.1 \pm 6.0$ & \\
\hline wPS & Avg & & $21-26$ & $120.5-130$ & $34.22 \pm 0.27$ & $3.0 \pm 1.2(\mathrm{n}=68)$ & $7.4 \pm 1.3$ & $4.9 \pm 4.9$ & $\begin{array}{l}\text { ORI-725 (Jul. 2004) } \\
\text { ORIII-1149 (May 2006) } \\
\text { ORI-837 (Jul. 2007)-Stn.A-D;1-5, } \\
\text { unpublished data from C. T. A. Chen }\end{array}$ \\
\hline
\end{tabular}

(NIST, U.S.A), 4.97 (San-Ying, Taiwan), 9.77 (Lien-Hwa, Taiwan) and 53 (All-Win, Taiwan) ppmV were used for calibration. The precision of repeated analysis of water samples was about $\pm 5 \%$ in routine sample analysis.

The concentration of the atmospheric $\mathrm{CH}_{4}$ was estimated by the GC-FID. Atmospheric $\mathrm{CH}_{4}$ samples were placed at the room temperature $\left(25^{\circ} \mathrm{C}\right)$ for more than $2 \mathrm{~h}$ and $2 \mathrm{~mL}$ of the gas in the serum bottle was injected into the $\mathrm{GC}$ to analyze the $\mathrm{CH}_{4}$ concentration. The precision of repeated analysis of air samples was about $\pm 3 \%$ in routine sample analysis.

\subsection{Saturation ratio}

The concentrations of the $\mathrm{CH}_{4}$ in the water samples were obtained from the concentrations that were measured in the headspace by subtracting the influence of atmospheric $\mathrm{CH}_{4}$ at the sampling sites and using the Bunsen coefficients to calculate the equilibrium solubility, which were described in Wiesenburg and Guinasso (1979).

Saturation, expressed in \%, was calculated using $R=\left(C_{o b s}\right)$ $\left.C_{e q}\right)^{*} 100$ where $C_{o b s}$ represents the observed concentration of gas dissolved in the water, and $C_{\boldsymbol{e q}}$ is the expected equilibrium water concentration.

\subsection{Fluxes}

Fluxes of $\mathrm{CH}_{4}$ across the air-water interface were estimated using $F=k\left(C_{w}-\beta C_{a}\right)$ where $k\left(\mathrm{~cm} \mathrm{~h}^{-1}\right)$ is the gas exchange coefficient, $C_{w}$ is the concentration of dissolved gas in the water $\left(\mathrm{mol} \mathrm{l}^{-1}\right), \beta$ is the Bunsen solubility, and $C_{a}$ is the atmospheric gas concentration. A positive flux indicates gas transfer from the water to the atmosphere. The value of $k$ is a specific function of properties of the gas, the temperature $\mathrm{T}\left({ }^{\circ} \mathrm{C}\right)$ and turbulence, and is frequently parameterized as a function of the wind speed $u\left(\mathrm{~m} \mathrm{~s}^{-1}\right)$. Many equations are used for calculating the $\mathrm{k} /$ wind speed relationship (Liss and Merlivat, 1986; Wanninkhof, 1992; Erickson, 1993; Nightingale et al., 2000). As Wanninkhof (1992) has been widely used and has recently been updated (Wanninkhof, 2014), here, we calculated $k$ by using the relationship established by Wanninkhof (2014). The updated relationship is expressed as $k=0.251 u^{2}(S c / 660)^{-0.5}$, where $k$ is the gas transfer velocity, $u^{2}$ is the average squared wind speed, and $S c$ is the Schmidt number, which is the kinematic viscosity of water divided by the molecular diffusion coefficient of the gas. The new estimates of the Schmidt number (Wanninkhof, 2014) are provided, expanding the temperature range from 0 to $30^{\circ} \mathrm{C}$ to -2 to $40{ }^{\circ} \mathrm{C}$. Wind speeds at $10 \mathrm{~m}$ above the surface were obtained from the National Aeronautics and Space Administration (NASA) QuikSCAT satellite platform (https:// winds.jpl.nasa.gov/missions/quikscat/). The average monthly wind speed was used to estimate the sea-to-air flux.

The seawater fluxes from the SCS to the wPS were calculated as described by Chen et al. (2001). The principle of conservation of water mass dictates that the water flowing into the SCS must be balanced by the water flowing out plus the water piled up within the SCS.

\section{Result and discussion}

\subsection{Atmospheric $\mathrm{CH}_{4}$ concentration}

The mean concentrations of $\mathrm{CH}_{4}$ in all atmospheric samples from the SCS and wPS were $1.81 \pm 0.04 \mathrm{ppm} \mathrm{V}$ and $1.82 \pm 0.04 \mathrm{ppmV}$, respectively. These values agreed closely with the mean monthly $\mathrm{CH}_{4}$ mixing ratios that were measured at stations of the Earth System Research Laboratory under the National Oceanic and Atmospheric Administration (NOAA-ESRL; http://www.esrl.noaa.gov/gmd/ccgg/ ggrn.php) in situ program. The mean $\mathrm{CH}_{4}$ mixing ratios at Station BKT (Bukit Kototabang; $0^{\circ} 12^{\prime} \mathrm{S}, 100^{\circ} 19^{\prime} \mathrm{E}$ ), Station GMI (Mariana Islands; $13^{\circ} 23^{\prime} \mathrm{N}, 144^{\circ} 39^{\prime} \mathrm{E}$ ) and Station MID (Sand Island; $28^{\circ} 12^{\prime} \mathrm{N}$, $\left.177^{\circ} 22^{\prime} \mathrm{E}\right)$ of NOAA-ESRL between 2003 and 2007 were $1.807 \mathrm{ppm} \mathrm{V}$ (1.805-1.809 ppm V), $1.785 \mathrm{ppm} \mathrm{V}(1.777-1.798 \mathrm{ppm} \mathrm{V)}$ and 1. 821 ppm V (1.817-1.827 ppm V), respectively.

\subsection{Surface seawater $\mathrm{CH}_{4}$ concentrations and sea-to-air $\mathrm{CH}_{4}$ fluxes}

The average surface $\mathrm{CH}_{4}$ concentration in the wPS was $3.0 \pm$ $1.2 \mathrm{nmol} \mathrm{L}^{-1}$ (155\% saturation). This value is greater than the $109 \%$ saturation that was reported by Rehder and Suess (2001) in the Pacific Ocean, east of Taiwan, and is also greater than that in the western North Pacific of $2.46 \pm 0.23 \mathrm{nmol} \mathrm{L}^{-1}$ (saturation 132\%) in 1991 (Watanabe et al., 1995) and $1.83-2.81 \mathrm{nmol} \mathrm{L}^{-1}$ in 1979 (Burke et al., 1983). In addition to the fact that the concentration of $\mathrm{CH}_{4}$ at the surface may increase in parallel with the atmospheric concentration (Watanabe et al., 1995), the surface water in the wPS is influenced by the waters from the SCS, which has higher $\mathrm{CH}_{4}$ concentrations than the wPS. As a result, the average surface $\mathrm{CH}_{4}$ concentration in the wPS was higher than other sites of the western North Pacific.

The mean surface $\mathrm{CH}_{4}$ concentration in the SCS was $4.5 \pm$ $3.6 \mathrm{nmol} \mathrm{L}^{-1}$ (saturation 230\%), and it was about 35\% higher than that in the wPS. The SCS receives a large amount of nutrients, in the form of river discharge, atmospheric fallout, and intensive upwelling 
(Chen and Huang, 1995; Chao et al., 1996). As a result, the surface water in the SCS contains more nutrients than that in the wPS (Liu et al., 2002; Chen et al., 2006). Higher nutrient contents lead to higher primary production. Although the so-called methane paradox, which concerns methanogenesis in an aerobic environment, has not yet been fully explained, substantial research indicated the possibility that biological processes are responsible for the formation of $\mathrm{CH}_{4}$ (Traganza et al., 1979; de Angelis and Lee, 1994; Karl and Tilbrook, 1994). The riverine input brings not only nutrients into the SCS but also a high concentration of $\mathrm{CH}_{4}$ (Chen et al., 2008a). Consequently, the surface $\mathrm{CH}_{4}$ concentrations in the SCS were higher than those in the wPS.

The sea-to-air $\mathrm{CH}_{4}$ flux in the wPS was $4.9 \pm 4.9 \mu \mathrm{mol} \mathrm{m}^{-2} \mathrm{~d}^{-1}$ and in the SCS it was higher at $8.6 \pm 6.4 \mu \mathrm{mol} \mathrm{m}^{-2} \mathrm{~d}^{-1}$. Most areas of the SCS were probably moderate to strong sources of atmospheric $\mathrm{CH}_{4}$, with sea-to-air flux values of $9.9 \pm 8.7 \mu \mathrm{mol} \mathrm{m}^{-2} \mathrm{~d}^{-1}$ in the northeastern SCS, $12.0 \pm 7.4 \mu \mathrm{mol} \mathrm{m}{ }^{-2} \mathrm{~d}^{-1}$ in the northern SCS and the Pearl River estuary region, $8.3 \pm 4.1 \mu \mathrm{mol} \mathrm{m}^{-2} \mathrm{~d}^{-1}$ in the southwestern SCS and $4.3 \pm 3.9 \mu \mathrm{mol} \mathrm{m}^{-2} \mathrm{~d}^{-1}$ in the eastern and southern SCS (Table 1).

In general, the observed saturations and fluxes of $\mathrm{CH}_{4}$ in the coastal, shelf and marginal seas varied greatly within a range of 74$10500 \%$ and $0.0095-1200 \mu \mathrm{mol} \mathrm{m}^{-2} \mathrm{~d}^{-1}$ (Table 2 and references therein). The observed saturations and fluxes of $\mathrm{CH}_{4}$ in the SCS and wPS in this study fell within these ranges. On a global scale, the mean surface $\mathrm{CH}_{4}$ concentration in the SCS is comparable to the North Aegean Sea, but higher than other areas such as the Arabian Sea, North Sea and the Yellow Sea (Table 2).

\subsection{Water and $\mathrm{CH}_{4}$ exchange between the SCS and the wPS}

Since the Luzon Strait is $2200 \mathrm{~m}$ deep, surface and intermediate waters are exchanged unimpededly between the SCS and the wPS. Yet, waters that are deeper than $2200 \mathrm{~m}$ in the wPS cannot enter the SCS. Hence, waters below $2200 \mathrm{~m}$ in the SCS are relatively homogeneous, with hydrochemical properties similar to the water at $2200 \mathrm{~m}$ in the wPS (Chen et al., 2006). In the wet season, surface and intermediate waters are net-exported from the SCS to the wPS but deep water is netimported (Chen et al., 2001). Chen et al. (2001) calculated the amount of surface water that flows out of the SCS through the Luzon Strait in the wet season as $13.9 \times 10^{6} \mathrm{t} \mathrm{s}^{-1}$ and the amount of wPS water that flows into the SCS as $12.8 \times 10^{6} \mathrm{t} \mathrm{s}^{-1}$. Based on our data, the $\mathrm{CH}_{4}$ concentration above $350 \mathrm{~m}$ in the SCS (SCS surface water layer) is 4.8 $\pm 5.7 \mathrm{nmol} \mathrm{L}^{-1}$; and in the wPS (wPS surface water layer), it is $3.9 \pm$ $1.9 \mathrm{nmol} \mathrm{L}^{-1}$ (Table 3). As a result, the net export of surface water from the SCS to the wPS carries $1.45 \times 10^{6} \mathrm{~mol} \mathrm{~d}^{-1} \mathrm{CH}_{4}$ in the wet season.

According to the observational data (Chen and Huang, 1996), the SCS Intermediate Water, defined by Chen and Huang (1996) as being at depths between 350 and $1350 \mathrm{~m}$, is a mixture of the upwelled deep water and the surface water. The Intermediate Water flows out of the SCS at a rate of $1.8 \times 10^{6} \mathrm{t} \mathrm{s}^{-1}$ (Chao et al., 1996; Chen and Huang, 1996). As the $\mathrm{CH}_{4}$ concentration of the SCS Intermediate Water was $3.4 \pm 3.0 \mathrm{nmol} \mathrm{L}^{-1}$, the SCS Intermediate Water exported $0.53 \times 10^{6} \mathrm{~mol} \mathrm{~d}^{-1} \mathrm{CH}_{4}$ to the wPS. The deep water below $1350 \mathrm{~m}$ flows into the SCS year-round at a rate of $1.2 \times 10^{6} \mathrm{t} \mathrm{s}^{-1}$ (Chao et al., 1996; Chen and Huang, 1996) and the $\mathrm{CH}_{4}$ concentration was $1.5 \pm$ $0.7 \mathrm{nmol} \mathrm{L}^{-1}$. Consequently, the deep water from the wPS exported $0.16 \times 10^{6} \mathrm{~mol} \mathrm{~d}^{-1} \mathrm{CH}_{4}$ to the SCS.

Briefly, the SCS exports $1.82 \times 10^{6} \mathrm{~mol} \mathrm{~d}^{-1} \mathrm{CH}_{4}$ to the wPS (net value) and emits $30.1 \times 10^{6} \mathrm{~mol} \mathrm{~d}^{-1} \mathrm{CH}_{4}$ to the atmosphere in the wet

Table 2

Compilation of $\mathrm{CH}_{4}$ measurements in various coastal, shelf and marginal seas.

\begin{tabular}{|c|c|c|c|c|c|c|}
\hline Study area & Station & Date & $\left.\begin{array}{l}\text { Surface } \mathrm{CH}_{4} \\
(\text { nmol L } \\
-1\end{array}\right)$ & $\begin{array}{l}\text { Saturation } \\
(\%)\end{array}$ & $\begin{array}{l}\text { Sea-to-air flux } \\
\left(\mu \mathrm{mol} \mathrm{m} \mathrm{m}^{-2} \mathrm{~d}^{-1}\right)\end{array}$ & Refs. \\
\hline NW Black Sea & 80 & Jul.-Aug. 1995 & $13.1 \pm 10.6$ & $173-10500$ & $32^{\mathrm{a}} ; 53^{\mathrm{b}}$ & Amouroux et al. (2002) \\
\hline \multirow[t]{5}{*}{ Arabian Sea } & 31 & Feb.-Mar. 1995 & & $173 \pm 54$ & $2.65 \pm 3.73^{\mathrm{a}}$ & Patra et al. (1998) \\
\hline & 19 & Jul.-Aug. 1995 & & $200 \pm 74$ & $5.02 \pm 4.59^{\mathrm{a}}$ & \\
\hline & 11 & Apr.-May 1994 & & $140 \pm 37$ & $0.032 \pm 0.162^{\mathrm{a}}$ & \\
\hline & & Apr.-May 1996 & $2.6-48$ & $140-2520$ & & Jayakumar et al. (2001) \\
\hline & & Aug.-Sept. 1997 & & & & \\
\hline \multirow[t]{2}{*}{ Baltic sea } & 63 & Feb. 1992 & & $113 \pm 5$ & $0.0095-14.5^{\mathrm{a}}$ & Bange et al. (1994) \\
\hline & 23 & Jul. 1992 & & $395 \pm 82$ & $0.101-1200^{\mathrm{a}}$ & \\
\hline Southern North Sea & 75 & Mar. 1989 & $2.5-43$ & $95-1430$ & $6-600^{\mathrm{a}}$ & Scranton and McShane (1991) \\
\hline \multirow[t]{2}{*}{ North Sea } & 117 & Sept. 1992 & & $126 \pm 8$ & $2.16 \pm 1.99^{\mathrm{a}}$ & Bange et al. (1994) \\
\hline & & $\begin{array}{l}\text { Aug. 1993; May 1995; } \\
\text { Oct. 1996; Apr. 1998; } \\
\text { Mar. 1999 }\end{array}$ & $2.0-67$ & $74-2245$ & & Upstill-Goddard et al. (2000) \\
\hline Northern & 14 & Jan. 1994 & $6.42 \pm 8.02$ & & $6.65 \pm 7.36^{\mathrm{b}}$ & Berner et al. (2003) \\
\hline \multicolumn{7}{|l|}{ Bay of Bengal } \\
\hline North Aegean Sea & $\sim 5$ & Jul. 1993 & $4.80 \pm 0.31$ & $231 \pm 32$ & $1.56^{\mathrm{a}}$ & Bange et al. (1996) \\
\hline South Aegean Sea & $\sim 30$ & Jul. 1993 & $3.17 \pm 0.45$ & $149 \pm 18$ & $1.90^{\mathrm{a}}$ & \\
\hline $\begin{array}{l}\text { Gulf of Lions } \\
\text { (Mediterranean Sea) }\end{array}$ & & Mar., June, Sept.-Nov. 1997; Jun. 1998 & $8-1360$ & & & Marty et al. (2001) \\
\hline Yellow Sea & 14 & Mar.-Apr. 2001 & $3.43 \pm 0.23$ & $121 \pm 5.4$ & $0.81 \pm 0.50^{\mathrm{a}}$ & Zhang et al. (2004) \\
\hline \multirow[t]{2}{*}{ East China Sea } & 29 & Apr. 2001 & $3.24 \pm 0.59$ & $141 \pm 23.6$ & $\begin{array}{l}1.63 \pm 1.67^{\mathrm{a}} \\
2.77 \pm 2.71^{\mathrm{b}}\end{array}$ & Zhang et al. (2008) \\
\hline & 21 & Sept. 2003 & $9.49 \pm 11.00$ & $487 \pm 555$ & $\begin{array}{l}20.9 \pm 54.8^{\mathrm{a}} \\
36.3 \pm 95.7^{\mathrm{b}}\end{array}$ & \\
\hline Western Philippine Sea & 68 & $\begin{array}{l}\text { Jul. } 2004 \\
\text { May } 2006 \\
\text { Jul. } 2007\end{array}$ & $3.0 \pm 1.2$ & $155 \pm 62$ & $4.9 \pm 4.9^{c}$ & This study \\
\hline South China Sea & 122 & $\begin{array}{l}\text { Aug., Sept., 2003; } \\
\text { Jul. 2004; Jul. 2005; } \\
\text { Jul. 2006; Jul. 2007 }\end{array}$ & $4.5 \pm 3.6$ & $230 \pm 184$ & $8.6 \pm 6.4^{\mathrm{c}}$ & This study \\
\hline
\end{tabular}

Flux estimations are follows.

${ }^{\mathrm{a}}$ Liss and Merlivat (1986).

b Wanninkhof (1992).

c Wanninkhof (2014). 
Table 3

$\mathrm{CH}_{4}$ concentrations, water fluxes and $\mathrm{CH}_{4}$ fluxes of various water masses in the SCS and wPS.

\begin{tabular}{|c|c|c|c|c|c|c|}
\hline & \multicolumn{3}{|l|}{ SCS } & \multicolumn{3}{|l|}{ wPS } \\
\hline & $\begin{array}{l}\text { Avg. Concentration } \\
\mathrm{nmol} \mathrm{L}\end{array}$ & $\begin{array}{l}\text { Water Flux } \\
\times 10^{6} \mathrm{t} \mathrm{s}^{-1}\end{array}$ & $\begin{array}{l}\mathrm{CH}_{4} \text { Flux } \\
\times 10^{6} \mathrm{~mol} \mathrm{~d}^{-1}\end{array}$ & $\begin{array}{l}\text { Avg. Concentration } \\
\mathrm{nmol} \mathrm{L}\end{array}$ & $\begin{array}{l}\text { Water Flux } \\
\times 10^{6} \mathrm{t} \mathrm{s}^{-1}\end{array}$ & $\begin{array}{l}\mathrm{CH}_{4} \text { Flux } \\
\times 10^{6} \mathrm{~mol} \mathrm{~d}^{-1}\end{array}$ \\
\hline $\begin{array}{l}\text { Surface Water Layer } \\
(0-350 \mathrm{~m})\end{array}$ & $4.8 \pm 5.7$ & $-13.9 \pm 1.8$ & -5.76 & $3.9 \pm 1.9$ & $12.8 \pm 1.1$ & 4.31 \\
\hline Intermediate water Layer (350-1350 m) & $3.4 \pm 3.0$ & $-1.8 \pm 0.4$ & -0.53 & & & \\
\hline Deep Water Layer (1350-2200 m) & & & & $1.5 \pm 0.7$ & $1.2 \pm 0.2$ & 0.16 \\
\hline
\end{tabular}

Positive and negative numbers represent inflow and outflow, respectively.

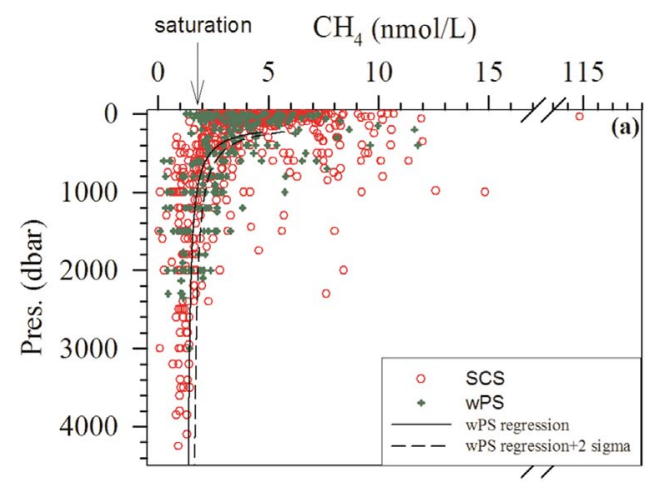

Chlorophyll $a(\mu \mathrm{g} / \mathrm{L})$

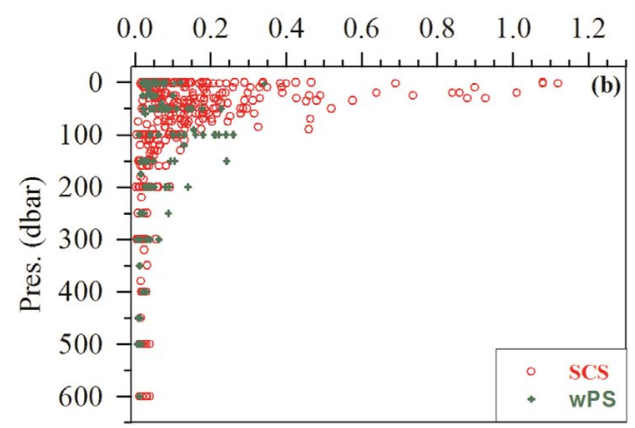

Fig. 2. Vertical distributions of (a) $\mathrm{CH}_{4}\left(\mathrm{nmol} \mathrm{L}^{-1}\right)$ and (b) chlorophyll $a\left(\mu \mathrm{g} \mathrm{L}^{-1}\right)$ in the western Philippine Sea, obtained at 43 stations during three cruises from July 2004 to July 2007 and in the South China Sea, obtained at 122 stations during six cruises from August 2003 to July 2007.

season. Therefore, the SCS exports $\mathrm{CH}_{4}$ to the atmosphere and the wPS, and the SCS emits more $\mathrm{CH}_{4}$ to the atmosphere than transports to the wPS.

\subsection{Sources of $\mathrm{CH}_{4}$ in the SCS and the wPS}

\subsection{1. $\mathrm{CH}_{4}$ sources in the surface layer of the wPS}

The concentrations of both $\mathrm{CH}_{4}$ and chlorophyll $a$ were high in the $150 \mathrm{~m}$ surface layer of the wPS (Fig. 2a and b), however, no significant correlation between $\mathrm{CH}_{4}$ and chlorophyll $a$ concentrations in the surface $150 \mathrm{~m}$ layer was identified herein.

Scranton and Brewer (1977) revealed the presence of a maximum $\mathrm{CH}_{4}$ concentration above the pycnocline in the western subtropical North Atlantic. A subsurface maximum has also been widely observed in the open sea (Burke et al., 1983; Watanabe et al., 1995; Kelley and Jeffrey, 2002). In fact, the subsurface $\mathrm{CH}_{4}$ maximum is common when examining the vertical $\mathrm{CH}_{4}$ distribution in the water column in the open sea. Although the formation of $\mathrm{CH}_{4}$ in the surface water layer may relate to the biological activity, and some studies (Owens et al., 1991; Damm et al., 2008; Zindler et al., 2013; Bogard et al., 2014) have indeed shown a correlation between the $\mathrm{CH}_{4}$ and chlorophyll $a$ concentrations in surface waters, no significant correlation between $\mathrm{CH}_{4}$ and chlorophyll $a$ concentrations in the surface $150 \mathrm{~m}$ layer was identified herein. This result not only shows that the formation of $\mathrm{CH}_{4}$ may not be directly associated with the photosynthetic process or phytoplankton biomass, as has been suggested in some studies (Zindler et al., 2013; Bogard et al., 2014), but it also reveals that other processes, such as the physical mixing of different water masses may affect the distribution of $\mathrm{CH}_{4}$ in the wPS.

\subsection{2. $\mathrm{CH}_{4}$ sources in the surface layer of the SCS}

$\mathrm{CH}_{4}$ maxima were observed in the subsurface layer at most stations (Fig. 2a) and the highest chlorophyll $a$ concentrations throughout the water column were found above $100 \mathrm{~m}$ (Fig. 2b). As for the wPS, no significant correlation between $\mathrm{CH}_{4}$ and chlorophyll $a$ concentrations in the surface $100 \mathrm{~m}$ layer was identified.

Domain B is near the Pearl River estuary where the hydrogeochemistry is influenced by the fresh water inputs, especially in the wet season (Yin et al., 2000). Chen et al. (2008a) reported extremely high $\mathrm{CH}_{4}$ concentrations from 23 to $2984 \mathrm{nmol} \mathrm{L}^{-1}$ in the Pearl River, its tributaries and estuary. Although the high $\mathrm{CH}_{4}$ concentration quickly declines offshore, rivers export a large amount of $\mathrm{CH}_{4}$ and organic matter into the coastal ocean. The riverine water brings large amounts of nutrients into the SCS (Dai et al., 2006, 2008; Chen et al., 2008a; Han et al., 2012), increasing the primary productivity and the chlorophyll $a$ concentration. The river inflow caused the surface water closer to shore to have lower salinity, higher chlorophyll $a$ and $\mathrm{CH}_{4}$ concentrations (Fig. 3). In 2005, a very large amount of fresh water flowed into the SCS and greatly reduced the salinity of seawater near shore (Fig. 3d). This very large amount of the fresh water was brought by the Super-typhoon Haitang (category 5 on the hurricane scale) close to this area one week before the research cruise, causing intense precipitation and increased river discharge. Fig. 4 shows that the surface $\mathrm{CH}_{4}$ concentration decreased with increasing salinity near the Pearl River estuary in 2005. Based on the linear equation (Fig. 4; $\left[\mathrm{CH}_{4}\right]$ $=-0.62$ salinity+26, $\mathrm{n}=19, \mathrm{r}^{2}=0.34$ ), when the salinity is $0, \mathrm{CH}_{4}$ concentration of the Pearl River in the estuary should be around 26 $\pm 6.9 \mathrm{nmol} \mathrm{L}^{-1}$, which falls within the range of $6.9-173.7 \mathrm{nmol} \mathrm{L}^{-1}$ reported by Zhou et al. (2009). This result indicates that the high surface $\mathrm{CH}_{4}$ concentration in domain $\mathrm{B}$ was caused by fresh water inputs, as was also reported in other areas such as the North Sea (Scranton and McShane, 1991; Rehder et al., 1998; Upstill-Goddard et al., 2000).

Domain C is in the southwestern SCS and most of it is on the Sunda Shelf. The sampling stations that were closer to the Mekong River estuary exhibited higher surface $\mathrm{CH}_{4}$ concentrations but lower salinity comparing with other sampling stations in Domain C (Fig. 5). It revealed that although the Mekong River mouth is more than $150 \mathrm{~km}$ away from the sampling stations, it still affected our sampling area. According to the model simulations, the Mekong River sediment can transport to more than $250 \mathrm{~km}$ away from the Mekong River mouth (Xue et al., 2012). In addition, the sediment core and isotopic data showed that over the past $5500 \mathrm{yrs}$, tremendous amount of Mekong River sediment input has allowed the Mekong River Delta to prograde 


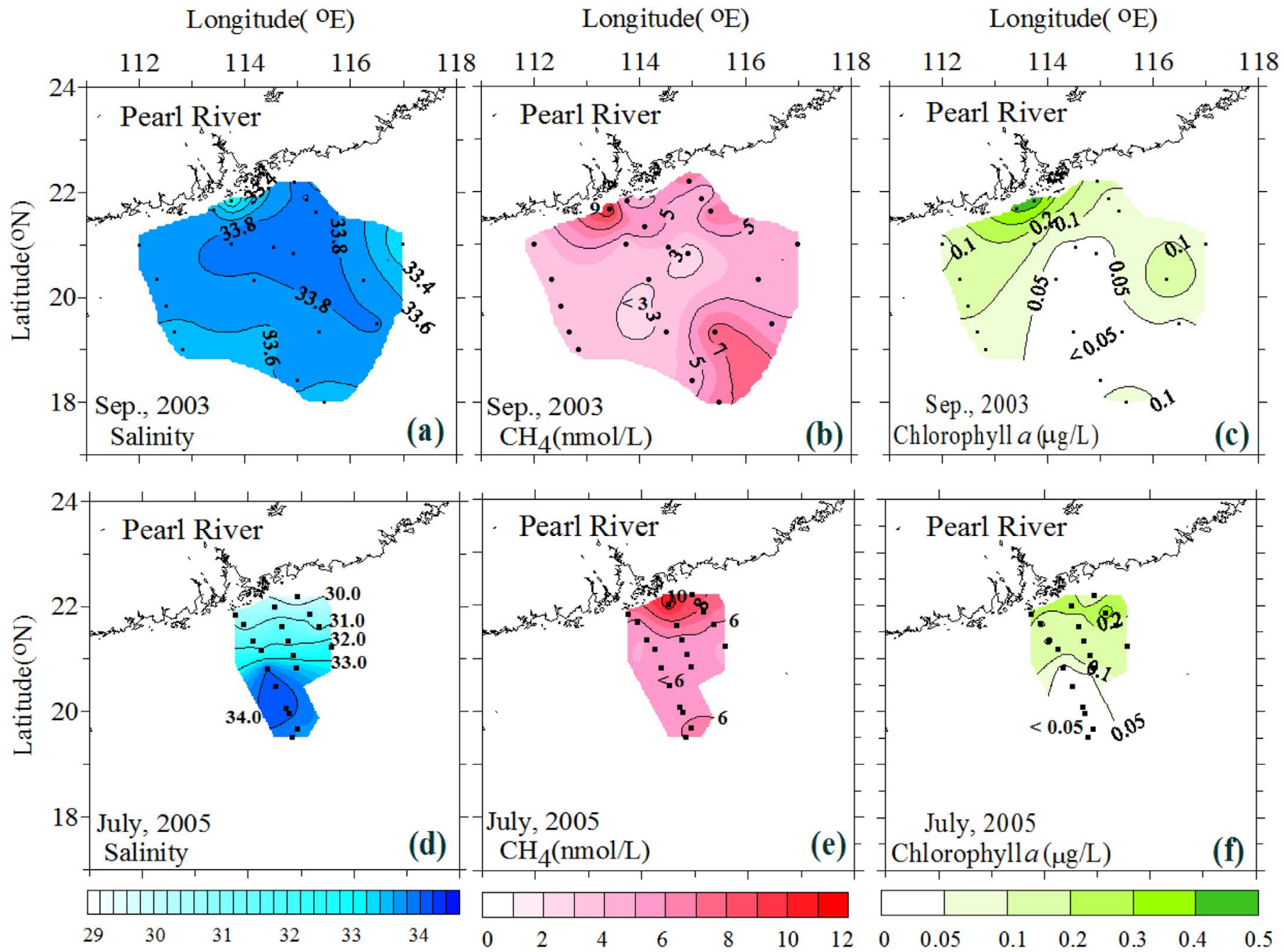

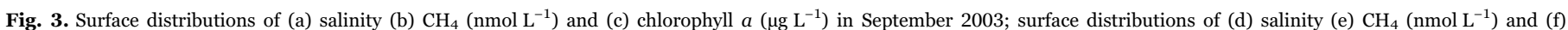
chlorophyll $a\left(\mu \mathrm{g} \mathrm{L}^{-1}\right)$ in July 2005 near the Pearl River estuary, obtained at 41 stations during two cruises in September 2003 and July 2005.

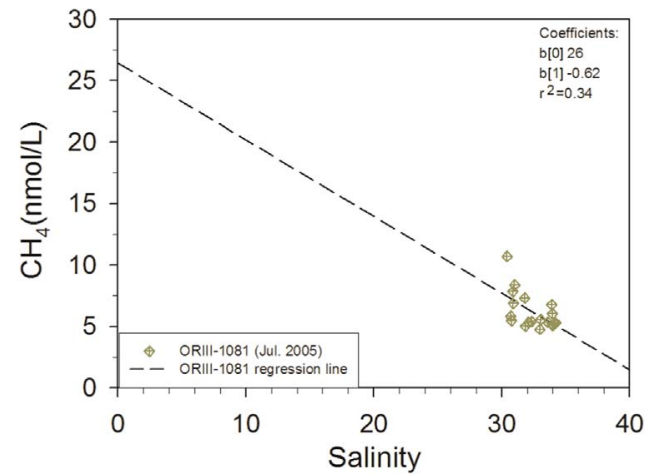

Fig. 4. Surface $\mathrm{CH}_{4}\left(\mathrm{nmol} \mathrm{L}^{-1}\right)$ versus salinity near the Pearl River estuary, obtained at 19 stations during one cruise in July 2005.

more than $250 \mathrm{~km}$ to the southeast (Nguyen et al., 2000).

\subsection{3. $\mathrm{CH}_{4}$ sources in the intermediate and deep water layers}

At most stations in the SCS and in the wPS (Fig. 2a), $\mathrm{CH}_{4}$ concentrations generally declined with increasing depth beyond the euphotic zone and remained constant below $1,000 \mathrm{~m}$. In the deep ocean, $\mathrm{CH}_{4}$ is typically undersaturated relative to the present atmospheric mixing ratio because of lower atmospheric $\mathrm{CH}_{4}$ concentrations at the time when deep water was formed (Rehder et al., 1999), and because of bacterial oxidation (Scranton and Brewer, 1978).
The average $\mathrm{CH}_{4}$ concentration in the deep water layer (1350$2200 \mathrm{~m}$ ) were $1.5 \pm 0.7 \mathrm{nmol} \mathrm{L}^{-1}$ in the wPS and $1.9 \pm 1.7 \mathrm{nmol} \mathrm{L}^{-1}$ in the SCS. However, there were some high $\mathrm{CH}_{4}$ concentrations (4.2$\left.14.8 \mathrm{nmol} \mathrm{L}^{-1}\right)$ at mid-depths (800-2300 m; Fig. 2a) in the SCS. High $\mathrm{CH}_{4}$ concentrations were found in the bottom water in the area between latitude $20-22^{\circ} \mathrm{N}$ and longitude $118-120^{\circ} \mathrm{E}$ (in Domain A) and stations \#19, \#20 (Fig. 6; in Domain B). These signals may be related to the sediments on the upper continental slope, which are rich in organic matter and $\mathrm{CH}_{4}$ may have been generated in the anoxic sediments. The same phenomenon has been observed in the East China Sea (ECS). For instance, Lin et al. (1992) found that the organic carbon concentrations in the bottom sediments increased across the shelf break, reaching their highest value in sediments at depths of 1000$1500 \mathrm{~m}$ in the ECS. Further, Zhang et al. (2008) found high concentrations of $\mathrm{CH}_{4}$ (around $40 \mathrm{nmol} \mathrm{L}^{-1}$ ) in bottom waters in the ECS, which may have been related to the production within and emission of $\mathrm{CH}_{4}$ from the organic-rich sediments. Tseng et al. (2016) reported in the same sampling area, high $\mathrm{N}_{2} \mathrm{O}$ concentrations which may have been produced in sediments on the continental slope.

Regions of $\mathrm{CH}_{4}$ seepage were also discovered in Domain A with buildups of authigenic carbonate, named the Jiulong Methane Reef (Suess, 2005; Han et al., 2005, 2008). Previous research (Suess et al., 1985; Boetius et al., 2000; Boetius and Suess, 2004) has reported that the formation of authigenic carbonates at cold vent sites of continental margin has been associated with methane-rich fluid and the activity of chemosynthetic communities. 

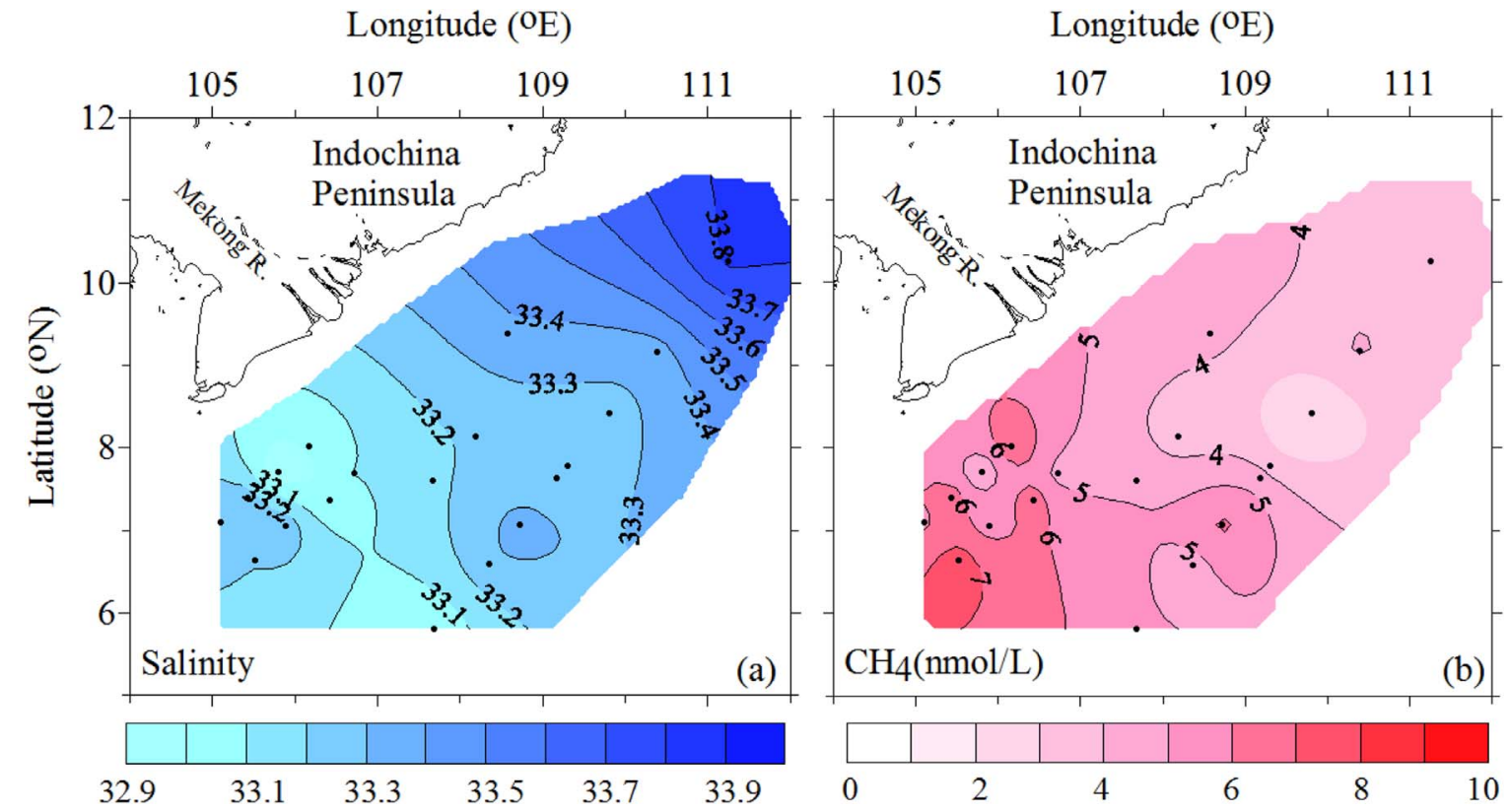

Fig. 5. Surface distributions of (a) salinity and (b) $\mathrm{CH}_{4}\left(\mathrm{nmol} \mathrm{L}^{-1}\right)$ near Mekong River estuary in the South China Sea, obtained at 19 stations during one cruise in July 2006.

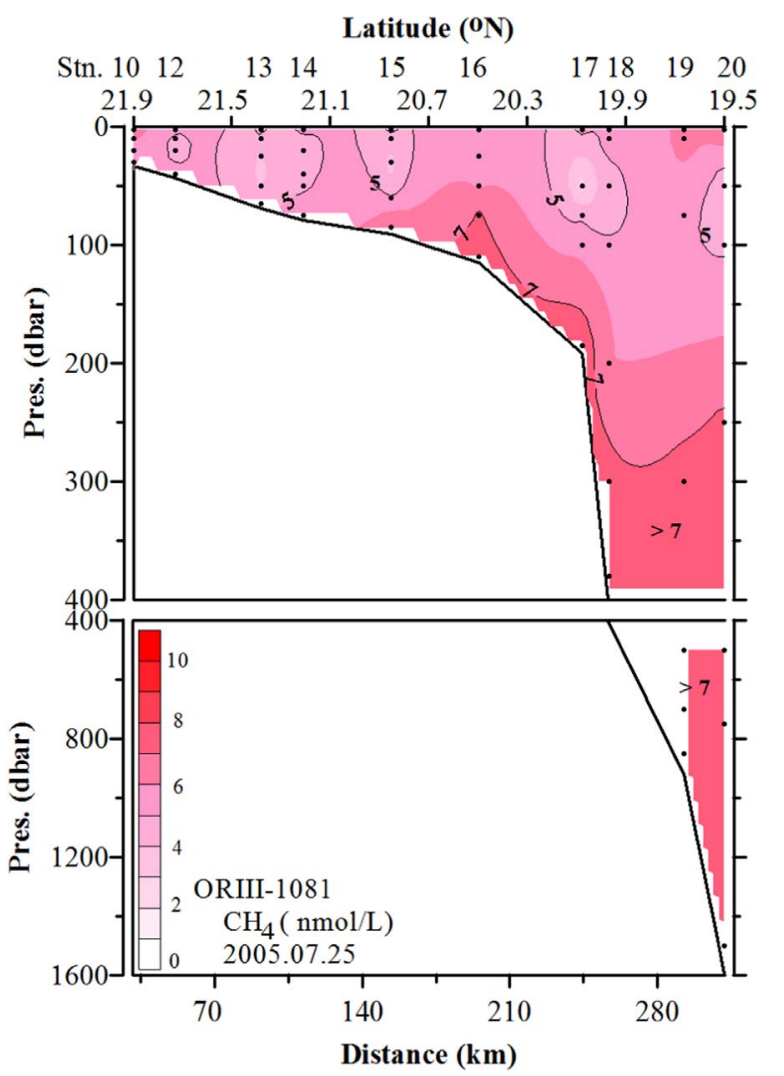

Fig. 6. Cross-section of $\mathrm{CH}_{4}\left(\mathrm{nmol} \mathrm{L}{ }^{-1}\right)$ near the Pearl River estuary, obtained at 10 stations during one cruise in July 2005.

The depths of sampling stations \#19 $\left(19^{\circ} 30.975^{\prime} \mathrm{N} ; 114^{\circ} 49.508^{\prime} \mathrm{E}\right)$ and \#20 (19 $\left.40.427^{\prime} \mathrm{N} ; 114^{\circ} 55.462^{\prime} \mathrm{E}\right)$ were 850 and $1500 \mathrm{~m}$, respectively. Worth mentioning is that both sampling stations had high $\mathrm{CH}_{4}$ concentrations throughout the water column (Fig. 7), which is not common in the deep sea domain. Zhou et al. (2009) reported high bottom $\mathrm{CH}_{4}$ concentrations (between latitude $18-20^{\circ} \mathrm{N}$ and longitude $113-116^{\circ} \mathrm{E}$ ) near these two sampling stations and possibly due to $\mathrm{CH}_{4}$ seeps from seafloor sediments. Wu et al. (2009) revealed that a large amount of hydrocarbon may be accumulated in the

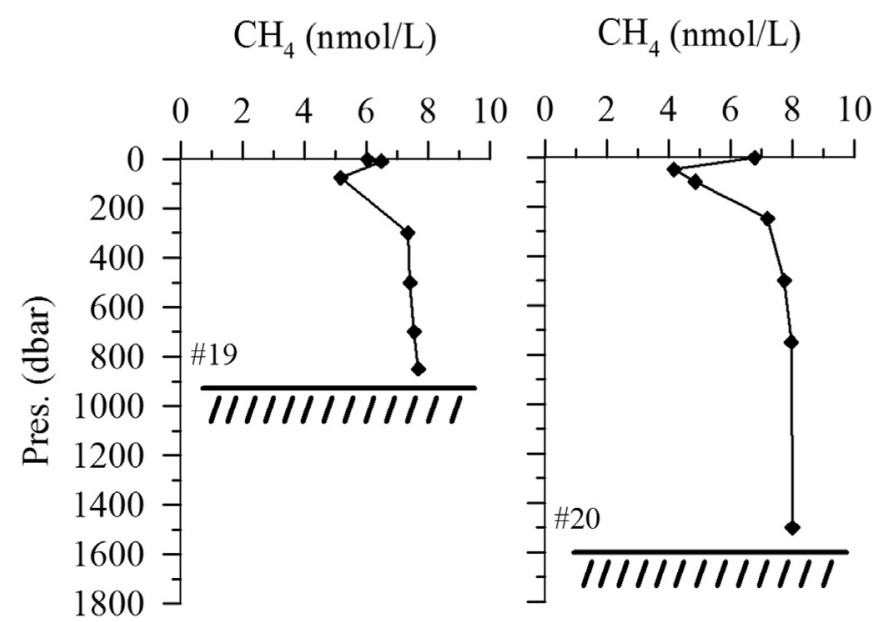

Fig. 7. Vertical distribution of the $\mathrm{CH}_{4}$ concentrations $\left(\mathrm{nmol} \mathrm{L}{ }^{-1}\right.$ ) at stations \#19 and \#20 near the Pearl River estuary in July 2005.

continental shelf of the SCS. Seismic profiles of these areas also show that bottom simulating reflectors (BSR) are widespread under the sea floor, indicative of possible gassy sediments (Wu et al., 2005). Additional geochemical evidence also suggests the presence of submarine gas hydrate deposits around these area (Chen et al., 2005; Su et al., 2005). As a result, these high mid-depth $\mathrm{CH}_{4}$ concentrations and especially the one that was $115 \mathrm{nmol} \mathrm{L}^{-1}$ at a depth of $35 \mathrm{~m}-$ most likely originated from gas hydrates (Chen and Tseng, 2006) and oil gas beneath the sediment with subsequent vertical migration and advection of $\mathrm{CH}_{4}$. The $\mathrm{CH}_{4}$ that is released from the seafloor will migrate upward through the water column either as dissolved $\mathrm{CH}_{4}$ or as bubbles (Zhang and Zhai, 2015).

Domain D includes the eastern and southern parts of the SCS, from the southern Luzon Strait southward along the western coast of Luzon, Palawan and Borneo. High surface $\mathrm{CH}_{4}$ concentrations were measured along the coast of Brunei (Fig. 8a), in agreement with previous study (Rehder and Suess, 2001). The occurrence of pockmarks, indicating the recent or ancient seepage of gas or fluid from the bottom, as well as some gas seeps that have recently been active, have been identified off the shore of Brunei (Hovland and Judd, 1988). Fig. 9 presents the cross-section between the eastern and the southern SCS in 2007 (ORI- 
(a)

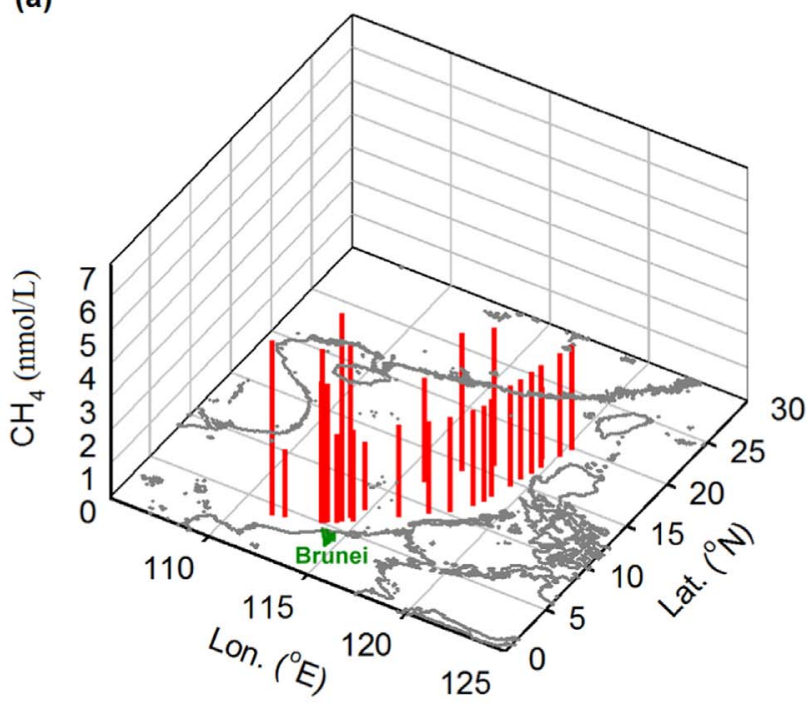

(b)

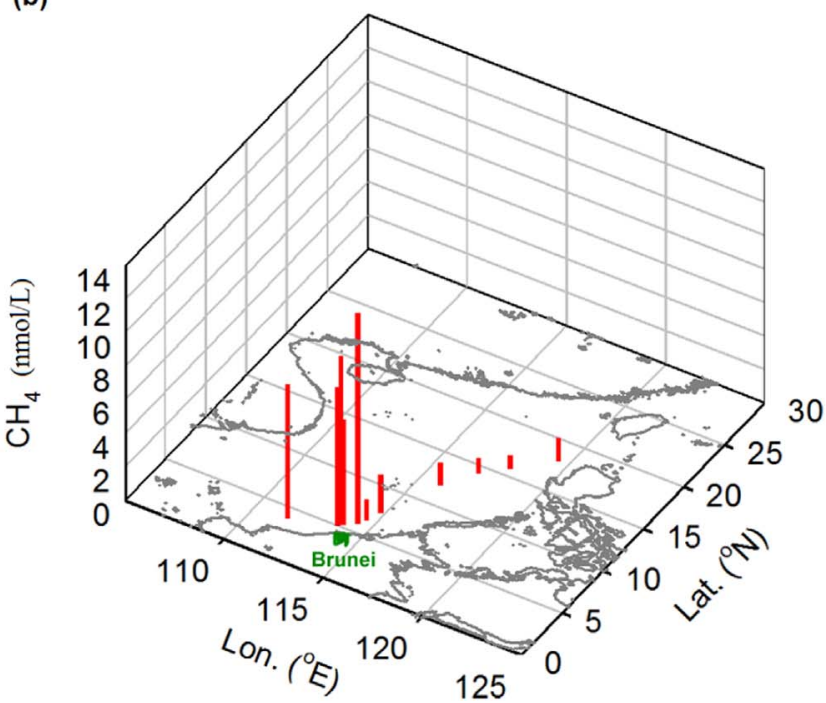

Fig. 8. Distribution of $\mathrm{CH}_{4}\left(\mathrm{nmol} \mathrm{L}^{-1}\right)$ in the (a) surface water and (b) bottom water in domain D (defined in Fig. 1a) in the South China Sea, obtained at 30 stations during one cruise in July 2007.

837). The water column of the section was well stratified in both salinity and temperature during the wet season (Fig. 9a and b). But surprisingly, from sampling station SL1-SL5 (near Brunei), the $\mathrm{CH}_{4}$ concentration did not decrease with the depth beyond euphotic zone but reaches the maxima in the bottom water (Fig. 9c). At all sampling stations near Brunei, high $\mathrm{CH}_{4}$ concentrations were found in the bottom waters (Fig. 8b). At sampling station SL1, the $\mathrm{CH}_{4}$ concentration reached $12.6 \mathrm{nmol} \mathrm{L}^{-1}$ in the bottom water at a depth of around $1000 \mathrm{~m}$. The high $\mathrm{CH}_{4}$ concentrations in the water column close to Brunei may reflect seepage from the abundant fossil fuel and gas deposits (OPL, 2000).

Chen and Huang (1996) and Chen et al. (2015) reported that a middepth boundary between $350 \mathrm{~m}$ and $1350 \mathrm{~m}$ exists near $122^{\circ} \mathrm{E}$ above the continental slope near the Luzon Strait. To the east of it, the water mass belongs to the wPS, whereas to the west, it is mainly the SCS water. Fig. 10 displays the $\mathrm{CH}_{4}$ vertical distribution above $2000 \mathrm{~m}$ along $22^{\circ} \mathrm{N}$ from $121^{\circ} \mathrm{E}$ to $126^{\circ} \mathrm{E}$. The $\mathrm{CH}_{4}$ vertical distribution in the intermediate water along $22^{\circ} \mathrm{N}$ reveals rather high $\mathrm{CH}_{4}$ concentrations west of $121.5^{\circ} \mathrm{E}$. These high $\mathrm{CH}_{4}$ concentrations in the intermediate water were presumably exported from the SCS. However, determining whether the high $\mathrm{CH}_{4}$ concentration signals disappeared east of $121.5^{\circ} \mathrm{E}$ because of mixing with the wPS intermediate water, which has a lower $\mathrm{CH}_{4}$ concentration, or because of being transferred north by the Kuroshio Current, requires further investigation.

The vertical distributions of $\mathrm{CH}_{4}$ in the SCS and the wPS (Fig. 2a) show that many $\mathrm{CH}_{4}$ data were higher in the SCS than in the wPS. Those higher $\mathrm{CH}_{4}$ concentrations appeared above $2300 \mathrm{~m}$ in the SCS and might come from the riverine input in the surface water layer or be released from the sediment in the intermediate and deep water layers. In order to exclude the effects of sea-air exchange and the influence from the fresh water and the SCS, the correlation between $\mathrm{CH}_{4}$ concentrations and potential temperature below $100 \mathrm{~m}$ in the wPS east of $121.5^{\circ} \mathrm{E}$ was examined (Fig. 11). The $\mathrm{CH}_{4}$ concentrations correlate positively with potential temperature $\left(\mathrm{CH}_{4}=0.12 \mathrm{~T}+1.28\right.$, $\mathrm{n}=103, \mathrm{r}^{2}=0.44$ ). As the water masses above $2200 \mathrm{~m}$ exchange freely between the wPS and the SCS, and waters deeper than about $2200 \mathrm{~m}$ originate in the $2200 \mathrm{~m}$ deep wPS water outside the Luzon Strait (Chen et al., 2001), the correlation of $\mathrm{CH}_{4}$ concentrations with potential temperature in the SCS should be similar with the one in the wPS. Therefore, the values above the linear regression plus 2 sigma were likely released from the sediment in the SCS (Fig. 11).

\section{5. $\mathrm{CH}_{4}$ in the continental shelf of the $\mathrm{SCS}$ and future aspects}

In the continental shelf and upper slope region (depth $<500 \mathrm{~m}$ ) of the SCS, the average surface $\mathrm{CH}_{4}$ concentration was $5.1 \pm 2.1 \mathrm{nmol} \mathrm{L}^{-1}$ while at depths of greater than $500 \mathrm{~m}$, it was $3.8 \pm 1.6 \mathrm{nmol} \mathrm{L}^{-1}$. Coastal regions receive more terrestrial nutrients and organic matter than deep seas, and the stronger coupling in such regions between sediments and surface waters favors high dissolved $\mathrm{CH}_{4}$ concentrations. During the wet season, the southwesterly monsoon induces upwelling along the coastal ocean over the continental shelf of the northern SCS (Shaw, 1992; Li, 1993; Su, 1998; Gan et al., 2009) and the Vietnamese coast (Ho et al., 2000; Kuo et al., 2000; Xie et al., 2003). During the dry season, the northeasterly monsoon causes coastal upwelling off northwest Borneo Island (Yan et al., 2015), resulting in the input of nutrients. Combining $\mathrm{CH}_{4}$ with wind speed data obtained using satellites yields estimated sea-to-air $\mathrm{CH}_{4}$ fluxes of $11.0 \pm 7.4 \mu \mathrm{mol} \mathrm{m} \mathrm{m}^{-2} \mathrm{~d}^{-1}$ in the continental shelf and upper slope regions, and $6.1 \pm 6.0 \mu \mathrm{mol} \mathrm{m}{ }^{-2} \mathrm{~d}^{-1}$ in the deep-sea regions of the SCS. The continental shelf and upper slope regions cover around $60 \%$ of the SCS area and account for approximately $72 \%$ of the $\mathrm{CH}_{4}$ emission from the SCS.

Global warming has increased the stratification of the surface ocean, possibly expanding oxygen minimum zones (Stramma et al., 2008), and possibly increasing $\mathrm{CH}_{4}$ production (Naqvi et al., 2010). Additionally, coastal regions are subject to increasing terrestrial inputs of nutrients and organic matter (Chen et al., 2008b; Howarth, 2008; Conley et al., 2009), and decomposition of the settled organic matter causes hypoxia when the oxygen at the bottom is insufficiently replenished. Consequently, an increasing number of coastal ecosystems are reported to exhibit hypoxia (Diaz and Rosenberg, 2008; Lui et al., 2014). Changes in nutrient and carbon exported from rivers have been demonstrated to affect exchange of biogenic trace gases, such as $\mathrm{CO}_{2}$ (Gypens et al., 2009) and DMS (Gypens and Borges, 2014), with the atmosphere. As increasing amounts of nutrients and organic matter have been exported from the land and the hypoxic areas of coastal oceans have been increasing, more $\mathrm{CH}_{4}$ may have accumulated in the coastal regions and more $\mathrm{CH}_{4}$ emission may occur in the future.

\section{Conclusions}

In both the SCS and the wPS, $\mathrm{CH}_{4}$ in the surface water was oversaturated with respect to the atmospheric equilibrium, and $\mathrm{CH}_{4}$ concentrations generally declined with increasing depth below the euphotic zone, but remained constant below $1,000 \mathrm{~m}$. In the SCS, some 
Longitude (OE)

(a)

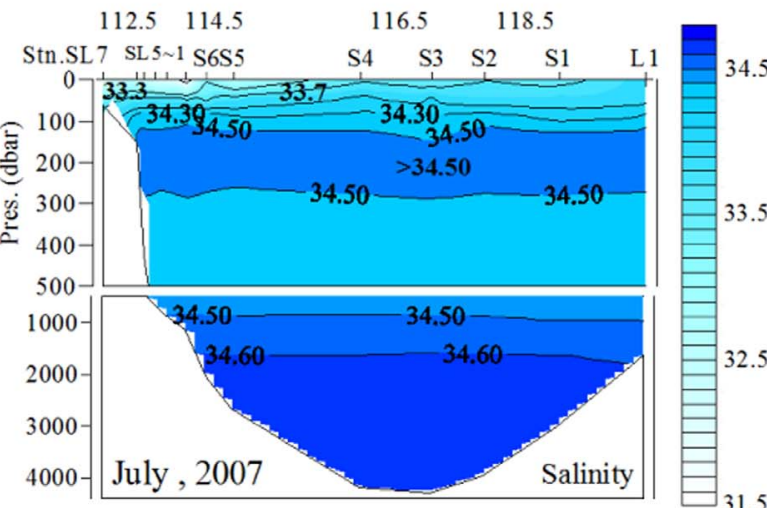

(b)

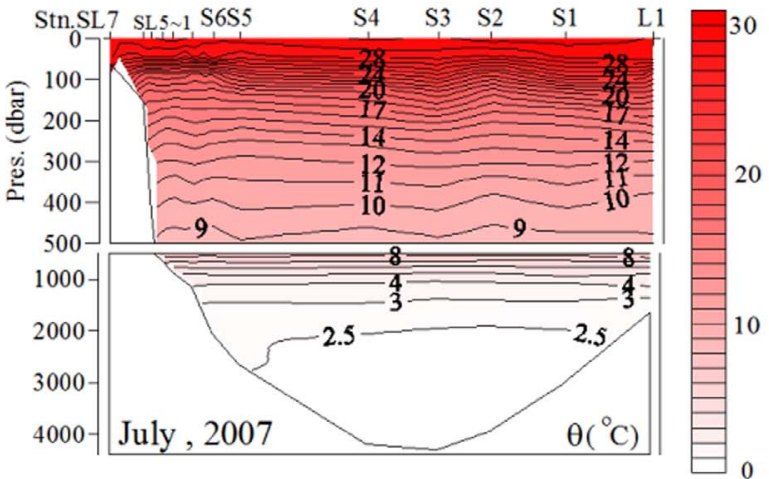

Longitude ( $\left.{ }^{\circ} \mathrm{E}\right)$

(c)

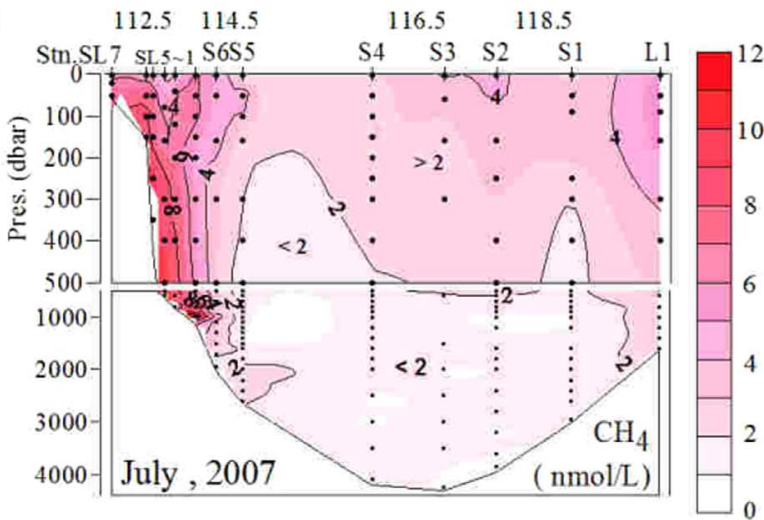

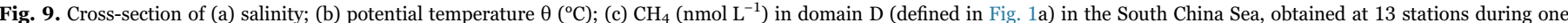
cruise in July 2007.

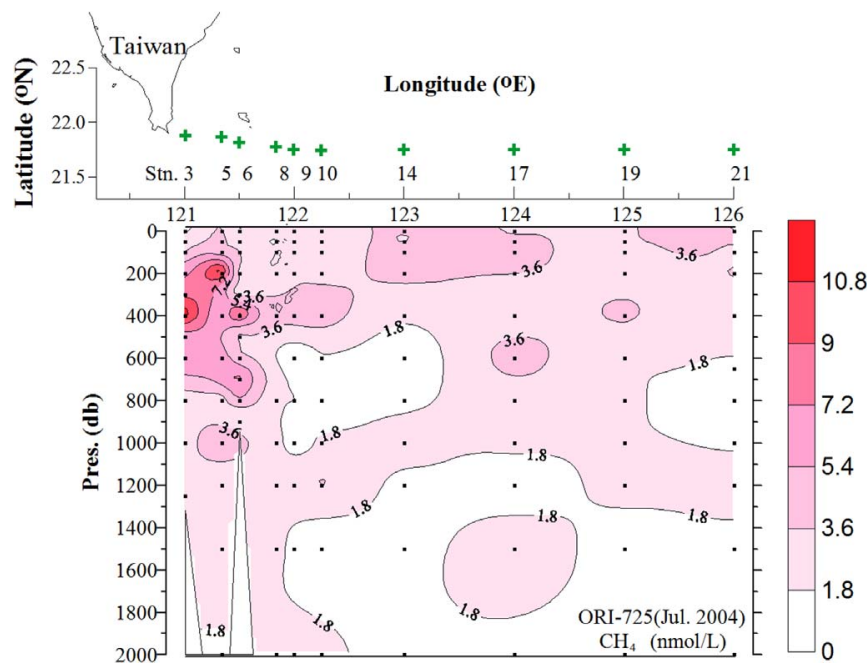

Fig. 10. Cross-section of $\left.\mathrm{CH}_{4}(\mathrm{nmol} \mathrm{L})^{-1}\right)$ along $22^{\circ} \mathrm{N}$ from $121^{\circ} \mathrm{E}$ to $126^{\circ} \mathrm{E}$ in the western Philippine Sea, obtained at 10 stations during one cruise in July 2004.

high $\mathrm{CH}_{4}$ concentrations at mid-depths were observed, and could most likely be attributed to the release of $\mathrm{CH}_{4}$ from sediments or seepage from gas hydrates or gassy sediment.

The SCS influences the surface and intermediate waters in the wPS. This study has established that the SCS emits $\mathrm{CH}_{4}$ to the atmosphere and also exports $\mathrm{CH}_{4}$ to the wPS. The SCS emits more $\mathrm{CH}_{4}$ to the atmosphere than transports to the wPS in the wet season.

The continental shelf and upper slope are responsible for approximately $72 \%$ of the emissions of $\mathrm{CH}_{4}$ from the SCS. Since marginal seas represent a large percentage of coastal regions and are strongly affected

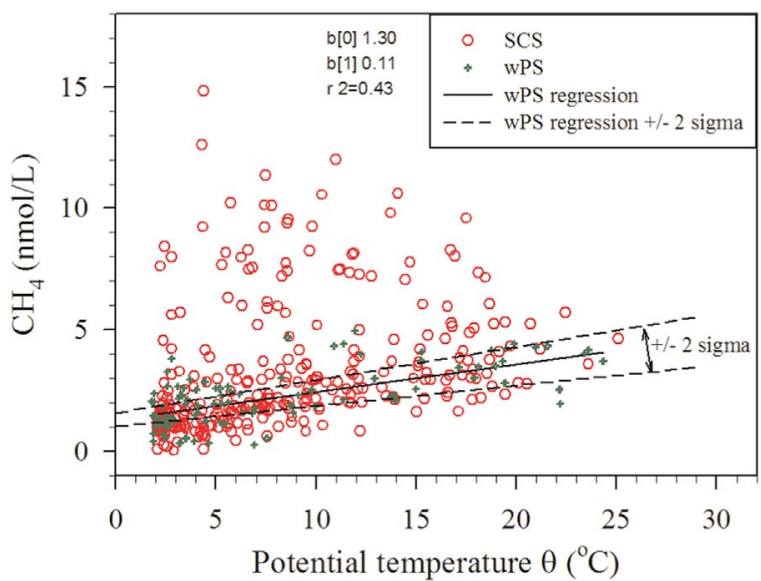

Fig. 11. The $\mathrm{CH}_{4}$ concentration $\left(\mathrm{nmol} \mathrm{L}{ }^{-1}\right.$ ) versus potential temperature $\theta\left({ }^{\circ} \mathrm{C}\right)$ below $100 \mathrm{~m}$ in the South China Sea and the western Philippine Sea, obtained at 66 stations during eight cruises from August 2003 to July 2007.

by anthropogenic activities, the situation in marginal seas may have become more severe comparing with other sea areas. Importantly, as terrestrial input increases and coastal areas under hypoxia expand, more $\mathrm{CH}_{4}$ may be emitted.

\section{Acknowledgements}

The authors wish to thank the Ministry of Science and Technology of the ROC, Taiwan (MOST 104-2611-M-110-015 and 104-2611-M110-016) and the Aim for the Top University Program Project (04C030204 and 05C030204), for supporting this research, and the captains and crews of ORI and III for their assistance, and two 
anonymous reviewers for constructive suggestions and comments on the previous version of the manuscript.

First author thanks the international grant from Bank Santander/ UNESCO Chair UNITWIN/WiCop and the Erasmus Mundus Programme for the MACOMA Doctoral funding contract (SGA 20121701/001-001-EMJD). AVB is a senior research associate at the Fonds National de la Recherche Scientifique (FNRS, Belgium).

\section{References}

Amouroux, D., Roberts, G., Rapsomanikis, S., Andreae, M.O., 2002. Biogenic gas $\left(\mathrm{CH}_{4}\right.$, $\mathrm{N}_{2} \mathrm{O}$, DMS) emission to the atmosphere from near-shore and shelf waters of the northwestern Black Sea. Estuar. Coast. Shelf Sci. 54, 575-587.

de Angelis, M.A., Lee, C., 1994. Methane production during zooplankton grazing on marine phytoplankton. Limnol. Oceanogr. 39, 1298-1308.

Bange, H.W., Rapsomanikis, S., Andreae, M.O., 1996. Nitrous oxide in coastal waters. Glob. Biogeochem. Cycles 10, 197-207.

Bange, H.W., Bartell, U.H., Rapsomanikis, S., Andrease, M.O., 1994. Methane in the Baltic and North Seas and a reassessment of the marine emission of methane. Glob. Biogeochem. Cycles 8, 465-480.

Berner, U., Poggenburg, J., Faber, E., Quadfasel, D., Frische, A., 2003. Methane in ocean waters of the Bay of Bengal: its sources and exchange with the atmosphere. Deep-Sea Res. II 50, 925-950.

Boetius, A., Suess, E., 2004. Hydrate ridge: a natural laboratory for the study of microbial life fueled by methane from near-surface gas hydrates. Chem. Geol. 204, 291-310.

Boetius, A., Ravenschlag, K., Schubert, C.J., Rickert, D., Widdel, F., Gieseke, A., Amann, R., Jørgensen, B.B., Witte, U., Pfannkuche, O., 2000. A marine microbial consortium apparently mediating anaerobic oxidation of methane. Nature 407, 623-626.

Bogard, M.J., del Giorgio, P.A., Boutet, L., Chaves, M.C.G., Prairie, Y.T., Merante, A., Derry, A.M., 2014. Oxic water column methanogenesis as a major component of aquatic $\mathrm{CH}_{4}$ fluxes. Nat. Commun., 5. http://dx.doi.org/10.1038/ncomms6350.

Borges, A.V., Champenois, W., Gypens, N., Delille, B., Harlay, J., 2016. Massive marine methane emissions from near-shore shallow coastal areas. Sci. Rep. 6, 27908. http:// dx.doi.org/10.1038/srep27908.

Burke, R.A., Jr., Reid, D.F., Brooks, J.M., Lavoie, D.M., 1983. Upper water column methane geochemistry in the eastern tropical North Pacific. Limnol. Oceanogr. 28, $19-32$.

Cao, Z.-M., Dai, M.-H., Zheng, N., Wang, D.-L., Li, Q., Zhai, W.-D., Meng, F.-F., Gan, J.P., 2011. Dynamics of the carbonate system in a large continental shelf system under the influence of both a river plume and coastal upwelling. J. Geophys. Res. 116, G02010. http://dx.doi.org/10.1029/2010JG001596.

Chang, H.L., Yang, S.S., 1997. Measurement of methane emission from soil. J. Chin Agric. Chem. Soc. 35, 475-484.

Chao, S.Y., Shaw, P.T., Wu, S.Y., 1996. Deep water ventilation in the South China Sea. Deep-Sea Res. 43, 445-466.

Chen, C.T.A., Huang, M.H., 1995. Carbonate chemistry and the anthropogenic $\mathrm{CO}_{2}$ in the South China Sea. Acta Oceanol. Sin. 14, 47-57.

Chen, C.T.A., Huang, M.H., 1996. A mid-depth front separating the South China Sea water and the West Philippine Sea water. J. Oceanogr. 52, 17-25.

Chen, C.T.A., Tseng, H.C., 2006. Abnormally high $\mathrm{CH}_{4}$ concentrations in seawater at mid-depths on the continental slops of the northern South China Sea. Terr. Atmos. Ocean. Sci. 17, 951-959.

Chen, C.T.A., Chen, Y.S., Wang, S.L., 1994. Methane emissions from natural waters in Taiwan. Proceedings of the 7th IUAPPA Regional Conference on Air Pollution and Waste Issues, Nov. 2-4, Taipei, VI, 51-61.

Chen, C.T.A., Wang, S.L., Lu, X.X., Zhang, S.R., Lui, H.K., Tseng, H.C., Wang, B.J., Huang, H.I., 2008a. Hydrogeochemistry and greenhouse gases of the Pearl River, its estuary and beyond. Q. Int. 186, 79-90.

Chen, C.T.A., Zhai, W.D., Dai, M.H., 2008b. Riverine input and air-sea $\mathrm{CO}_{2}$ exchanges near the Changiiang (Yangtze River) Estuary: status quo and implication on possible future changes in metabolic status. Cont. Shelf Res. 28, 1476-1482.

Chen, C.T.A., Wang, S.L., Wang, B.J., Pai, S.C., 2001. Nutrient budgets for the South China Sea basin. Mar. Chem. 75, 281-300.

Chen, C.T.A., Hou, W.P., Gamo, T., Wang, S.L., 2006. Carbonate-related parameters of subsurface waters in the West Philippine, South China and Sulu Seas. Mar. Chem. 99, 151-161.

Chen, C.T.A., Yeh, Y.T., Chen, Y.C., Huang, T.H., 2015. Seasonal and ENSO-related interannual variability of subsurface fronts separating West Philippine Sea waters from South China Sea waters near the Luzon Strait. Deep-Sea Res. I 103, 13-23.

Chen, D.F., Huang, Y.Y., Feng, D., Su, Z., 2005. Seep carbonate and preserved bacteria fossils in the northern South China Sea and their geological implications. Bull. Min. Pet. Geochem. 24, 185-189, (in Chinese).

Chuang, P.C., Yang, T.F., Lin, S., Lee, H.F., Lan, T.F., Hong, W.L., Liu, C.S., Chen, J.C., Wang, Y., 2006. Extremely high methane concentration in bottom water and cored sediments from offshore southwestern Taiwan. Terr. Atmos. Ocean. Sci. 17, 903-920.

Conley, D.J., Bj”orck, S., Bonsdorff, E., Carstensen, J., Destouni, J., G., Gustafsson, B.G., Hietanen, S., Kortekaas, M., Kuosa, H., Meier, H.E.M., Müller-Karulis, B., Nordberg, K., Norkko, A., Nürnberg, G., Pitkänen, H., Rabalais, N.N., Rosenberg, R., Savchuk, O.P., Slomp, C.P., Voss, M., Wulff, F., Zillén, L., 2009. Hypoxia-related processes in the Baltic Sea. Environ. Sci. Technol. 43, 3412-3420.

Dai, M., Guo, X., Zhai, W., Yuan, L., Wang, B., Wang, L., Cai, P., Tang, T., Cai, W.-J., 2006. Oxygen depletion in the upper reach of the Pearl River estuary during a winter drought. Mar. Chem. 102, 159-169.

Dai, M., Zhai, W., Cai, W.-J., Callahan, J., Huang, B., Shang, S., Huang, T., Li, X., Lu, Z. Chen, W., Chen, Z., 2008. Effects of an estuarine plume-associated bloom on the carbonate system in the lower reaches of the Pearl River estuary and the coastal zone of the northern South China Sea. Cont. Shelf Res. 28 (12), 1416-1423.

Dai, M.-H., Cao, Z.-M., Guo, X.-H., Zhai, W.-D., Liu, Z.-Y., Yin, Z.-Q., Xu, Y.-P., Gan, J.P., Hu, J.-Y., Du, C.-J., 2013. Why are some marginal seas sources of atmospheric $\mathrm{CO}_{2}$ ? Geophys. Res. Lett. 40, 2154-2158. http://dx.doi.org/10.1002/grl.50390.

Damm, E., Kiene, R.P., Schwarz, J., Falck, E., Dieckmann, G., 2008. Methane cycling in Arctic shelf water and its relationship with phytoplankton biomass and DMSP. Mar. Chem. 109, 45-59.

Damm, E., Helmke, E., Thoms, S., Schauer, U., Nöthing, E., Bakker, K., Kiene, R.P., 2010. Methane production in aerobic oligotrophic surface water in the central Artic Ocean. Biogeosciences 7, 1099-1108.

Diaz, R.J., Rosenberg, R., 2008. Spreading dead zones and consequences for marine ecosystems. Science 321, 926-929.

Du, C., Liu, Z., Dai, M., Kao, S.-J., Cao, Z., Zhang, Y., Huang, T., Wang, L., Li, Y., 2013. Impact of the Kuroshio intrusion on the nutrient inventory in the upper northern South China Sea: insights from an isopycnal mixing model. Biogeosciences 10, 6419-6432. http://dx.doi.org/10.5194/bg-10-6419-2013.

Erickson, D.J., III, 1993. A stability dependant theory for air-sea gas exchange. J. Geophys. Res. 98, 8471-8488.

Florez-Leiva, L., Damm, E., Farías, L., 2013. Methane production induced by dimethylsulfide in surface water of an upwelling ecosystem. Prog. Oceanogr. 112$113,38-48$.

Forster, G., Upstill-Godard, R.C., Gist, N., Robinson, C., Uher, G., Woodward, E.M.S., 2008. Nitrous oxide and methane in the Atlantic Ocean between $50^{\circ} \mathrm{N}$ and $52^{\circ} \mathrm{S}$ : latitudinal distribution and sea-to-air flux. Deep-Sea. Res. Pt. II 56, 964-976. http:// dx.doi.org/10.1016/jdsr2.2008.12.002.

Gan, J.-P., Li, L., Wang, D.-X., Guo, X.-G., 2009. Interaction of a river plume with coastal upwelling in the northeastern South China Sea. Cont. Shelf Res. 29, 728-740.

Gypens, N., Borges, A.V., 2014. Increase in dimethylsulfide (DMS) emissions due to eutrophication of coastal waters offsets their reduction due to ocean acidification. Front. Mar. Sci. 1 (4), 1-6. http://dx.doi.org/10.3389/fmars.2014.00004.

Gypens, N., Borges, A.V., Lancelot, C., 2009. Effect of eutrophication on air-sea $\mathrm{CO}_{2}$ fluxes in the coastal Southern North Sea: a model study of the past 50 years. Glob. Change Biol. 15, 1040-1056. http://dx.doi.org/10.1111/j.1365-2486.2008.01773.x.

Han, A.-Q., Dai, M.-H., Kao, S.-J., Gan, J.-P., Li, Q., Wang, L.-F., Zhai, W.-D., Wang, L. 2012. Nutrient dynamics and biological consumption in a large continental shelf system under the influence of both a river plume and coastal upwelling. Limnol. Oceanogr. 57, 486-502.

Han, W.-Y., 1998. Marine Chemistry in the South China Sea. Science Press, Beijing, 289, (in Chinese).

Han, X., Suess, E., Huang, Y., Wu, N., Bohrmann, G., Su, X., Eisenhauer, A., Rehder, G., Fang, Y., 2008. Jiulong methane reef: microbial mediation of seep carbonates in the South China Sea. Mar. Geol. 249, 243-256.

Han, X., Suess, E., Huang, Y., Wu, N., Eisenhauer, A., Bohrmann, G., Su, X., Rehder, G., Fang, Y., shipboard scientists of Leg SO-177, 2005. Jiulong Methane reef: first direct evidence of methane seepage in the South China Sea. Geophysical Research Abstracts 7, 04055. European Geosciences Union.

Ho, C.-R., Zheng, Q., Soong, Y.S., Kuo, N.-J., Hu, J.-H., 2000. Seasonal variability of sea surface height in the South China Sea observed with TOPEX/POSEIDON altimeter data. J. Geophys. Res. 105, 13981-13990.

Hovland, M., Judd, A.J., 1988. Seabed Pockmarks and Seepages. Graham and Trotman, London, 293.

Howarth, R.W.. 2008. Coastal nitrogen pollution: a review of sources and trends globally and regionally. Harmful Algae 8, 14-20.

Huang, T.H., Chen, C.T.A., Zhang, W.Z., Zhuang, X.F., 2015. Varying intensity of Kuroshio intrusion into Southeast Taiwan Strait during ENSO events. Cont. Shelf Res, 103, 79-87.

Intergovernmental Panel on Climate Change (IPCC), 2013. Working Group I Report, The Physical Science Basis. C.2; C.6; C.8, pp. 159-254; pp. 473-552; pp. 677-731.

Jayakumar, D.A., Naqvi, S.W.A., Narvekar, P.V., George, M.D., 2001. Methane in coastal and offshore waters of the Arabian Sea. Mar. Chem. 74, 1-13.

Johnson, K.M., Hughes, J.E., Donaghay, P.L., Sieburth, J.M., 1990. Bottle-calibration static head space method for the determination of methane dissolved in seawater. Anal. Chem. 62, 2408-2412.

Karl, D., Beversdorf, L., Björkman, K.M., Church, M.J., Martinez, A., DeLong, E.F., 2008 Aerobic production of methane in the sea. Nat. Geosci. 1, 473-478.

Karl, D.M., Tilbrook, B.D., 1994. Production and transport of methane in oceanic particulate organic matter. Nature 368, 732-734.

Kelley, C.A., Jeffrey, W.H., 2002. Dissolved methane concentration profiles and air-sea fluxes from $41^{\circ} \mathrm{S}$ to $27^{\circ} \mathrm{N}$. Glob. Biogeochem. Cycles $16,131-136$.

Kirschke, S., Bousquet1, P., Ciais1, P., Saunois1, M., Canadell, J.G., Dlugokencky, E.J., Bergamaschi, P., Bergmann, D., Blake, D.R., Bruhwiler, L., Cameron-Smith, P. Castaldi, S., Chevallier, F., Feng, L., Fraser, A., Fraser1, P.J., Heimann, M., Hodson, E.L., Houweling, S., Josse, B., Krummel, P.B., Lamarque, J.-F., Langenfelds, R.L., Le Quéré, C., Naik, V., O’Doherty, S., Palmer, P.I., Pison1, I., Plummer, D., Poulter1, B., Prinn, R.G., Rigby, M., Ringeval, B., Santini, M., Schmidt, M., Shindell, D.T., Simpson, I.J., Spahni, R., Steele, L.P., Strode, S.A., Sudo, K., Szopa1, S., van der Werf, G.R., Voulgarakis, A., van Weele, M., Weiss, R.F., Williams, J.E., Zeng, G., 2013. Three decades of global methane sources and sinks. Nat. Geosci. 6, 813-823.

Kuo, N.-J., Zheng, Q., Ho, C.-R., 2000. Satellite observation of upwelling along the western coast of the South China Sea. Remote Sens.Environ. 74, 463-470.

Lamontagne, R.A., Swinnerton, J.W., Linnenbom, V.J., Smith, W.D., 1973. Methane concentrations in various marine environments. J. Geophys. Res. 78, 5317-5324. 
Li, L., 1993. Summer upwelling system over the northern continental shelf of the South China Sea: a physical description. In: Su, J., Chuang, W.-S., Hsueh, R.Y. (Eds.), Proceedings of the Symposium on the Physical and Chemical Oceanography of the China Seas. China Ocean Press, Beijing, 58-68.

Lin, S., Liu, K.-K., Chen, M.-P., Chang, F.-Y., 1992. Distribution of organic carbon in the KEEP area continental margin sediments. Terr. Atmos. Ocean. Sci. 3, 365-378.

Liss, P.S., Merlivat, L., 1986. Air-sea Gas Exchange Rates: Introduction and Synthesis. The Role of Air-Sea Exchange in Geochemical Cyclings. NATO ASI Series 185. D. Reidel Publishing Company, New York, 113-127.

Liu, K.K., S.-Y. Chao, S.Y., Shaw, P.-T., Gong, G.-C., Chen, C.-C., Tang, T.Y., 2002. Monsoon-forced chlorophyll distribution and primary production in the South China Sea: observations and a numerical study. Deep-Sea Res. I 49, 1387-1412.

Lui, H.K., Chen, C.T.A., Lee, J., Bai, Y., He, X.Q., 2014. Looming hypoxia on outer shelves caused by reduced ventilation in the open oceans: case study of the East China Sea. Estuar. Coast. Shelf Sci. 151, 355-360. http://dx.doi.org/10.1016/ j.ecss.2014.08.010.

Marty, D., Bonin, P., Michotey, V., Bianchi, M., 2001. Bacterial biogas production in coastal system affected by freshwater inputs. Cont. Shelf Res. 21, 2105-2115.

Morales, C.E., Anabalón, V., 2012. Phytoplankton biomass and microbial abundances during the spring upwelling season in the coastal area off Concepción, centralsouthern Chile: variability around a time series station. Prog. Oceanogr. 92 (1), $81-91$.

Naqvi, S.W.A., Bange, H.W., Farías, L., Monteiro, P.M.S., Scranton, M.I., Zhang, J., 2010. Marine hypoxia/anoxia as a source of $\mathrm{CH}_{4}$ and $\mathrm{N}_{2} \mathrm{O}$. Biogeosciences 7, 2159-2190.

Nguyen, L.V., Ta, T.K.O., Tateishi, M., 2000. Late holocene depositional environments and coastal evolution of the Mekong River Delta, Southern Vietnam. J. Asian Earth Sci. 18 (4), 427-439.

Nightingale, P.D., Malin, G., Law, C.S., Watson, A.J., Liss, P.S., Liddicoat, M.I., Boutin, J., Upstill-Goddard, R.C., 2000. In situ evaluation of air-sea gas exchange parameterizations using novel conservative and volatile tracers. Glob. Biogeochem. Cycles 14, 373-387.

OPL, 2000. South East Asia Oil \& Gas Activity and Concession Map 2000 ed.. Oilfield Publications, Herefordshire.

Owens, N.J.P., Law, C.S., Mantoura, R.F.C., Burkill, P.H., Llewellyn, C.A., 1991. Methane flux to the atmosphere from the Arabian Sea. Nature 354, 293-296.

Patra, P.K., Lal, S., Venkataramani, S., Gauns, M., Sarma, V.V.S.S., 1998. Seasonal variability in distribution and fluxes of methane in the Arabian Sea. J. Geophys. Res. 103, 1167-1176.

Rehder, G., Suess, E., 2001. Methane and $\mathrm{pCO}_{2}$ in the Kuroshio and the South China Sea during maximum summer surface temperatures. Mar. Chem. 75, 89-108.

Rehder, G., Keir, R.S., Suess, E., 1999. Methane in the northern Atlantic controlled by microbial oxidation and atmospheric history. Geophys. Res. Lett. 5, 587-590.

Rehder, G., Keir, R.S., Suess, E., Pohlmann, T., 1998. The multiple sources and patterns of methane in North Sea waters. Aquat. Geochem. 4, 403-427.

Rhee, T.S., Kettle, A.J., Andreae, M.O., 2009. Methane and nitrous oxide emissions from the ocean: a reassessment using basin-wide observations in the Atlantic. J. Geophys. Res. 114, D12304. http://dx.doi.org/10.1029/2008JD011662.

Scranton, M.I., Brewer, P.G., 1977. Occurrence of methane in the near surface waters of the western subtropical North-Atlantic. Deep-Sea Res. 24, 127-138.

Scranton, M.I., Brewer, P.G., 1978. Consumption of dissolved methane in the deep ocean. Limnol. Oceanogr. 23 (6), 1207-1213.

Scranton, M.I., McShane, K., 1991. Methane in the southern North Sea: the role of European rivers. Cont. Shelf Res. 11 (1), 37-52.

Shaw, P.T., 1992. Self circulation off the southeast coast of China. Rev. Aquat. Sci. 6 (1), $1-28$.

Sheu, W.-J., Wu, C.-R., Oey, L.-Y., 2010. Blocking and westward passage of eddies in the Luzon Strait. Deep-Sea Res. II. http://dx.doi.org/10.1016/j.dsr2.2010.04.004.

Stramma, L., Johnson, G.C., Sprintall, J., Mohrholz, V., 2008. Expanding oxygenminimum zones in the tropical oceans. Science 320, 655-658

Strickland, J.D.H., Parsons, T.R., 1972. A Practical Handbook of Seawater Analysis. Fisheries Research Board of Canada, Ottawa, Canada, 310.

Su, C.Y., Niu, B.H., Wang, H.Y., Zhao, K.B., 2005. A study of gas hydrate geochemical exploration and deposit formation patterns in the Xisha ocean. Earth Sci. Front. 12, 243-251, (in Chinese).

$\mathrm{Su}, \mathrm{J} ., 1998$. Circulation dynamics of the China seas north of $18^{\circ} \mathrm{N}$. In: Allan, R.R.,
Kenneth, H., Brink (Eds.), The Sea, Vol. 11, The Global Coastal Ocean: Regional Studies and Syntheses. Wiley, NY, 483-505.

Suess, E., 2005. RV SONNE cruise report SO 177, Sino-German cooperative project, South China Sea Continental Margin: geological methane budget and environmental effects of methane emissions and gashydrates. IFM-GEOMAR Reports. $\langle$ http://store. pangaea.de/documentation/Reports/SO177.pdf .

Suess, E., Carson, B., Ritger, S., Moore, J.C., Jones, M., Kulm, L.D., Cochrane, G., 1985 Biological communities at vent sites along the subduction zones off Oregon. In: Jones, M.L. (ed), The hydrothermal vents of the Eastern Pacific: An Overview. Bull Biol Soc Wash, 6, 475-484.

Traganza, E.D., Swinnerton, J.W., Cheek, C.H., 1979. Methane supersaturation and ATPzooplankton blooms in near-surface waters of the Mediterranean and the subtropical North Atlantic Ocean. Deep-Sea Res. 26, 1237-1245.

Tseng, H.C., Chen, C.T.A., Borges, A.V., DelValls, T.A., Lai, C.M., Chen, T.Y., 2016. Distributions and sea-to-air fluxes of nitrous oxide in the South China Sea and the West Philippines Sea. Deep-Sea Res. I 115, 131-144.

Upstill-Goddard, R.C., Barnes, J., Frost, T., Punshon, S., Owens, N.J.P., 2000. Methane in the southern North Sea: low-salinity inputs, estuarine, and atmospheric flux. Glob. Biogeochem. Cycles 14, 1205-1216.

Wanninkhof, R., 1992. Relationship between wind speed and gas exchange over the ocean. J. Geophys. Res. 97 (C5), 7373-7382.

Wanninkhof, R., 2014. Relationship between wind speed and gas exchange over the ocean revisited. Limnol. Oceanogr.: Methods 12, 351-362.

Watanabe, S., Higashitani, N., Tsurushima, N., Tsunogai, S., 1995. Methane in the western North Pacific. J. Oceanogr. 51, 39-60.

Wiesenburg, D.A., Guinasso, N.L., Jr, 1979. Equilibrium solubilities of methane, carbon monoxide, and hydrogen in water and seawater. J. Chem. Eng. Data 24, 356-360.

Wu, S.G., Zhang, G.X., Huang, Y.Y., 2005. Gas hydrate occurrence on the continental slope of the northern South China Sea. Mar. Petrol. Geol. 22, 403-412.

Wu, S.G., Sun, Q.L., Wu, T.Y., Yuan, S.Q., Ma, Y.B., Yao, G.S., 2009. Polygonal fault and oil-gas accumulation in deep-water area of Qiongdongnan Basin. Acta Pet. Sin. 30, 22-32, (in Chinese)

Xie, S.-P., Xie, Q., Wang, D., Liu, W.T., 2003. Summer upwelling in the South China Sea and its role in regional climate variations. J. Geophys. Res. 108 (C8), 3261. http:// dx.doi.org/10.1029/2003JC001867.

Xue, Z., He, R., Liu, J.P., Warner, J.C., 2012. Modeling transport and deposition of the Mekong River sediment. Cont. Shelf Res. 37, 66-78.

Yan, Y., Ling, Z., Chen, C., 2015. Winter coastal upwelling off northwest Borneo in the South China Sea. Acta Oceanol. Sin. 34, 3-10.

Yang, T.F., Chuang, P.C., Lin, S., Chen, J.C., Wang, Y., Chung, S.H., 2006. Methane venting in gas hydrate potential area offshore of SW Taiwan: evidence of gas analysis of water column samples. Terr. Atmos. Ocean. Sci. 17, 933-950.

Yin, K., Qian, P., Chen, Jv.C., Hsieh, D.P.H., Harrison, P.J., 2000. Dynamics of nutrients and phytoplankton biomass in the Pearl River estuary and adjacent waters of Hong Kong during summer: preliminary evidence for phosphorus and silicon limitation. Mar. Ecol.: Prog. Ser. 194, 295-305.

Yuan, Y., Liao, G., Yang, C., 2008. The Kuroshio near the Luzon Strait and Circulation in the Northern South China Sea during August and September 1994. J. Oceanogr. 64, 777-788. http://dx.doi.org/10.1007/s10872-008-0065-6.

Zhang, G., Zhang, J., Ren, J., Li, J., Liu, S., 2008. Distributions and sea-to-air fluxes of methane and nitrous oxide in the North East China Sea in summer. Mar. Chem. 110, 42-55.

Zhang, G.L., Zhang, J., Kang, Y.B., Liu, S.M., 2004. Distributions and fluxes of dissolved methane in the East China Sea and the Yellow Sea in spring. J. Geophys. Res. 109 (C7), C07011. http://dx.doi.org/10.1029/2004JC002268.

Zhang, Y., Zhai, W.-D., 2015. Shallow-ocean methane leakage and degassing to the atmosphere: triggered by offshore oil-gas and methane hydrate explorations. Front. Mar. Sci. 2, 34. http://dx.doi.org/10.3389/fmars.2015.00034.

Zhou, H., Yin, X., Yang, Q., Wang, H., Wu, Z., Bao, S., 2009. Distribution, source and flux of methane in the western Pearl River Estuary and northern South China Sea. Mar. Chem. 117, 21-31.

Zindler, C., Bracher, A., Marandino, C.A., Taylor, B., Torrecilla, E., Kock1, A., Bange, H.W., 2013. Sulphur compounds, methane, and phytoplankton: interactions along a north-south transit in the western Pacific Ocean. Biogeosciences 10, 3297-3311. 